\title{
La Convivencia según la Escuela Agustiniana Española del siglo XVI
}

\section{CUESTIONES PREVIAS}

\section{1.- LA COMUNIDAD}

La palabra comunidad viene de communitas y esta de communis. Munis es el que cumple un deber, el que lleva una carga. Communis es el que comparte una carga, un deber ${ }^{1}$. Común es lo opuesto a propio; es lo público frente a lo privado o particular. Términos muy usados en el derecho romano y en san Agustín, aunque quizá no bien captados en las implicaciomes espirituales que en él conllevan.

Comunidad, dice el DRAE, es "calidad de común, de lo que, no siendo privativamente, pertenece o se extiende a varios "; "junta o congregación de personas que viven unidas bajo ciertas constituciones y reglas, como los conventos, colegios, etc."2. María Moliner la define así: "asociación de personas que tienen intereses comunes"3.

Las comunidades religiosas, entre cristianos, tienen un objetivo común a todas ellas: seguir a Jesucristo. Pero este seguimiento ha tenido muchas y muy distintas formas a lo largo de la historia, y tendrá muchas más. Cada comunidad lo concreta, lo llena de contenido. Para ello se da unas normas; organiza su vida de comunidad y su apostolado, o lo prohibe. Con el tiempo, se van solidificando en ella, coagulando, determinados usos y costumbres, ciertas tradiciones. Es la vida que se congela; es el hábitat de esa comunidad, que con el tiempo degenera en máscara.

1. Cf. A. ERNOUT y A. MEILLET, Dictionnaire étymologique de la langue latine, Editions Klincksieck, Paris 1974, 4ª s. v. munis.

2. REAL ACADEMIA ESPAÑOLA, Diccionario de la lengua española, Madrid 1992, $21^{\text {a }}$, s.v. comunidad.

3. Diccionario de uso del español, Editorial Gredos, Madrid 1966, s.v. comunidad. 


\section{2.- LA CONVIVENCIA}

Convivir es vivir con. Dos o más personas conviven, viven juntas. "Convivir, dice el DRAE, vivir en compañía de otro u otros, cohabitar". Compañero, etimológicamente, es quien come el pan con otro, el que comparte el pan. Se puede convivir o vivir en compañía de muchas maneras

Hay una convivencia pasiva. Dos o más individuos viven juntos. Están ahí, en una misma casa; trabajan en una misma oficina, o rezan juntos en un mismo oratorio, o duermen en un mismo dormitorio corrido, con la precaución, como manda la Regla de san Benito, de que los jóvenes no tengan sus camastros contiguos, sino mezclados con los de los viejos ${ }^{4}$, que el demonio no duerme. Las relaciones entre los que así conviven son nulas. Quizá recen unos por otros; pero todo queda en su interior. Fuera, silencio absoluto. Cada cual en su mundo y Dios en el de todos. No se tratan y, por no tratarse, se vuelven, es natural, intratables, hoscos, enfurruñados. Onagros, es decir, asnos salvajes, se llamaban a sí mismos los monjes, porque al onagro tenían por animal emblemático y por lema su cerrilismo. Soy así, dirá tal vez alguno de ellos. No: te has hecho y te han hecho así.

Pero hay también, y es la más común, una convivencia activa. El hombre sale de sí mismo, de su soledad, en busca de compañía; actualiza la mera posibilidad de relacionarse, el simple estar abierto a los demás. Entra en contacto con otros y estos le responden: se reciprocan. Hablan ente sí, colaboran, establecen proyectos comunes, o se insultan y andan a puñetazos. La convivencia entre ellos se ha hecho activa5.

\section{3.- LAS RELACIONES HUMANAS}

Las relaciones, en la convivencia activa, pueden ser muy variadas. Podemos clasificarlas en sociales, psíquicas y personales 6

Hay relaciones humanas sociales. Relaciones de despacho y ventanilla. Es la relación que establecemos, por ejemplo, con el guardia de tráfico al que le preguntamos dónde queda tal calle. Los que se relacionan son personas, pero lo hacen impersonalmente. Esta relación puede llegar a ser muy asidua, porque son muchos los asuntos que hay que despachar con determinada per-

4. Regla, XXII, 7 .

5. Entre los autores que pueden leerse sobre el particular, están Husserl, Unamuno, Ortega y Gasset, Zubiri, Laín Entralgo, Julián Marías, Lévinas, Mounier, Buber, Rof Carballo, Jean Lacroix, Nédoncelle, F. Ebner, Manuel Cabada, G. Bastide, López Quintás, Tzvetan Todorov, José Antonio Marina ... 
sona. La relación, sin embargo, no pasa de ser social. Se conocen, incluso se saludan; pero no pasan de ahí.

La relación puede ser psíquica. Las personas dejan de serse desconocidas. El trato entre ellas se va haciendo próximo, cercano. El otro ya no es alguien indeterminado. Comienza a ser individualizado, con rasgos precisos, inconfundibles. Se conoce, en parte, cómo piensa, qué afectos tiene, qué hace, en qué cree, con quiénes se relaciona, cuáles son sus proyectos. Su vida no es ajena; se la siente próxima, interesa. La vida de los que así se tratan se va entretejiendo, creándose entre ellos amplias zonas comunes. Se coincide o se disiente, pero en uno y otro caso se comparte.

Hay casos en que la relación se hace personal. El trato llega a la intimidad. Un índividuo único, irreductible, determinadísimo, incanjeable con cualquier otro, se relaciona como tal individuo con otro u otros que reúnen las mismas características. Se son mutuamente, se conocen personalmente, íntimamente. Se relacionan desde su reducto personalísimo, que les es mutuamente patente. Es la relación que se da entre padres e hijos, entre amantes, entre amigos en sentido estricto. Todos recordamos el trazado que, con mano maestra, hizo san Agustín de la amistad en las Confesiones ${ }^{7}$, aunque, al teorizar sobre ella, introdujo sus reflexiones neoplatónicas y la dejó no poco averiada.

Anda por ahí suelta la especie de que en la comunidad religiosa todos tienen que ser amigos. ¿Todos amigos? Ningun amigo. Si santo Tomás de Villanueva aconsejó a los misioneros agustinos que tratasen a los indios como amigos, es prueba de que tenía un concepto muy particular de la amistad, que no es ciertamente el nuestro. Se trata, en su caso, de una amistad espiritual, por la que se ama con amor espiritual a todos. Se los ama en Dios, por Dios y para Dios. En Dios, es decir, unidos a Dios, viviendo en él, en gracia de Dios, que se recibe en el bautismo y, si se pierde, se recupera en la confesión. Por Dios, porque lo manda él. Para Dios, para que sirvan a Dios en esta vida y después le gocen en la gloria. Esto era para él ser amigos de los indios

\section{4.- PASAdo y PRESENTE DE LA CONVIVENCIA}

¿Cómo tenía que ser la convivencia según la Escuela Agustiniana Española del siglo XVI? ¿Pasiva o activa? ¿Cómo se relacionaban los religiosos entre sí? ¿Se conocían? ¿Se amaban? ¿Con qué amor? Esto es lo que quisiera aclarar en estas páginas.

6. Julián MARÍAS, Mapa del mundo personal, Alianza Editorial, Madrid 1993, 14-17, 160-164 y passim.

7. IV, 8, 13 . 
Doy un avance. Se ha dicho por varios investigadores que los escritores religiosos del siglo XVI no hablan de la comunidad. Hoy que está este tema en el centro de nuestras preocupaciones, su ausencia es lo primero que se advierte al leerlos 8 . Pero, en realidad, sí que hablan de la comunidad. Quien habla del silencio, por ejemplo, y da normas sobre él está hablando de la comunidad. De lo que no hablan es de las relaciones humanas, de la convivencia activa. $\mathrm{O}$ mejor, hablan de ella, pero en sentido negativo. La convivencia es lo que hay que evitar; es lo que nos aparta de Dios. Y esto, estar en Dios, con el pensamiento fijo en él, disparados hacia él los deseos, debe ser la única preocupación del religioso. "Nunca deje derramar su corazón, aunque sea por un credo"9. Varios siglos antes, san Agustín se arrepiente, y confiesa su pecado, de quedarse absorto en la contemplación de un perro que corría tras una liebre, con el consiguiente apartamiento de altas contemplaciones divinas ${ }^{10}$ Estos hombres tenían una estructura mental diferente de la nuestra, distintos sentimientos y actitudes, por más que nos empeñemos en hablar de fidelidad al carisma del fundador.

Al tratar de la convivencia, nos encontramos, pues, solos; con una tradición adversa a la espalda; necesitados, por esto mismo, de redescubrir la novedad del Evangelio. Si el futuro se construye apoyándose en el pasado, con qué tiento tendremos que andar para evitarlo; para no recaer en sus errores; para librarnos de las mallas que nos tendió, y en las que aún estamos presos; para dar muerte al Casiano que todos llevamos dentro, tanto más peligroso cuanto menos conscientes seamos de él. No le habremos leído, pero le leyeron los padres de nuestros padres en la vida religiosa, y ahí sigue, desafiando el tiempo como una lapa las tormentas marinas. Nos encontramos solos, sin mapas del mundo que vamos a explorar. Tendremos que ir descubriéndolo solos, y descubrir es aquí crear formas nuevas de convivencia y levantar sus mapas, es decir, teorizar sobre ellas ${ }^{11 .}$

Voy a estudiar la convivencia en cuatro autores agustinos del siglo XVI: santo Tomás de Villanueva, beato Alonso de Orozco, fray Luis de León y fray Pedro Malón de Chaide.

8. Cf. José Vicente RODRÍGUEZ, Juan de la Cruz y su estilo de hacer comunidad, en Confer 31 (1992) 33-62; Ignacio IGLESIAS, Ignacio de Loyola y un nuevo modo de ser y de hacer comunidad, en Confer 30 (1991) 213; Antonio MAS ARRONDO, El hombre en Cristo y Cristo en el hombre, Burgos 1993, 51 n- 90 (es un estudio sobre santa Teresa); Jesús DÍEZ, La comunidad en la Forma de vivir, en Mayéutica 15 (1989) 177-249 (estudio sobre fray Luis de León); Id., Fray Alonso de Orozco, el escritor y catequista, en Recollectio 14 (1991) 198

9. San JUAN DE LA CRUZ, Dichos de luz y amor, $\mathrm{n}^{\circ} .145$.

10. Cf. Confesiones, X, 35, 57.

11. Cf. José VEGA, La convivencia, en Estudio Agustiniano 30 (1995) 491-515. 


\section{SANTO TOMÁS DE VILLANUEVA}

\section{5.-Plática A UN NOVICIO}

Santo Tomás de Villanueva escribió una Plática y aviso al religioso que toma hábito ${ }^{12}$. ¡Excelente ocasión esta de instruir a un novicio para hablar de la convivencia! Excelente para nosotros, pero no para él, y a su texto me remito. Ni para él ni para sus contemporáneos. Este silencio exige una explicación. Las que para nosotros son evidencias no lo eran para ellos y al revés. En la visión de una cosa, tan importante como el rayo que viene de ella a nosotros es el que va de nosotros a ella, decía Ortega. Vemos desde lo que sabemos, desde nuestra entera subjetividad. Cada individuo tiene su ángulo de visión, y lo tiene cada generación y cada época. Cada uno ve unas cosas y otras no, y las que ve las ve de una manera y no de otra.

La plática parte de Deut. 11,10s, texto en el que Yahvé instruye a su pueblo sobre las diferencias entre Egipto, tierra de sembradura y regadío, y la tierra a la que se encaminan, tierra de montes, dependiente de las lluvias del cielo.

Obedézcanle a él, guarden los mandamientos que les ha dado, sírvanle sólo a él, y él les enviará la lluvia temprana y la tardía, y tendrán cosechas abundantes. La explicación que da el santo es una alegoría de este texto.

\section{a) Huida del mundo}

El novicio ha salido de Egipto, del mundo, y ha entrado en el monasterio, tierra de promisión. En Egipto hay descanso, alegría, holgura, deleites corporales, consolaciones carnales, aguas de regadío. El monasterio, en cambio, es tierra de montes, áspera, sin deleites ni consuelos bajos y terrenos. En él, los deleites vienen de arriba, de la lluvia que el Señor envía, de la gracia. Con ella, se anda por las cuestas y montañas con presteza, como María (Lc 1, 39). Cuanto más huya del mundo, cuanto más atrás deje a Egipto, más le llenarán los consuelos del Señor.

Pero el novicio viene del mundo, y no es fácil borrar de la memoria "cuanto impreso dejó allí el vivir loco"13. Además, el demonio y la carne se aliarán con el mundo contra él. Tiene que estar preparado para la tentación.

12. En Obras de santo Tomás de Villanueva. Sermones de la Virgen y obras castellanas, Introducción, versión y notas deI P. Santos Santamarta, BAC, Madrid 1952. Los números que aparecen entre paréntesis, dentro del texto, remiten a las páginas de esta edición.

13. Fray Luis de LEÓN, Poesías, XV, vv. 27-28, en Obras completas castellanas, edic. del P. Félix García, BAC, Madrid 1951, 1951, $2^{\text {a }}$. 
Olvide el pasado, los pensamientos y deseos terrenos: este es el significado del rapado de cabeza que le hacen al entrar en religión. Pero la raíz de los malos deseos sigue en él. Esté sobre aviso, y apenas crezcan, rapado y desecho.

\section{b) Contemplación y acción}

"Tierra de montes y de vegas" es la tierra a la que se encaminaba Israel y lo es el monasterio. En él hay contemplativos, que andan por los montes, lejos del común, y activos. De las dos clases hay en los agustinos, donde el novicio ha entrado. Activos son los que aún no han llegado a la contemplación. Se están purificando. "Como son los menos los contemplativos verdaderos, hay activos más, y a todos no se da la contemplación" (564). Si no puede subir al monte de la contemplación, quédese en el valle de la vida activa,"que es también buena, aunque vale poco sin la otra, y por eso ejercitaros habéis lo mejor que pudiéredes en la contemplación, aunque sea poco" ( $\mathrm{Ib}$.). Será ese poco de contemplación lo que le sostenga en esos otros ejercicios activos, que no debe abandonar, aunque compruebe lo poco que valen para aquella. Nada peor le puede ocurrir que quedarse sin estos y sin contemplación. Eso sería salir de Egipto y no llegar a la tierra de promisión; quedarse sin este mundo y sin el otro.

\section{c) Aspereza de la vida religiosa}

Por eso, examínese el novicio si vale o no para religioso, "no sea que os pongáis en lugar más alto de para lo que sois" (565). Hacerlo es exponerse a un juicio de Dios más riguroso. Este es camino alto, estrecho, no es para todos. La carne no tiene aquí lugar ; hay que dejarla fuera, en el siglo. Un mismo pecado es más grave en el fraile que en el seglar. "Pensadlo bien y miradlo" (565).

\section{d) Necesidad de la gracia}

Tierra es esta que aguarda las lluvias del cielo. Sin ellas, trabajará en balde. "El hombre de sí no tiene sino mal" (566), pecado. Necesita la gracia. "Sin ella iréis de peor en peor y tornaros habéis más pecador" (Ib.). Pídala y espérela. Pero no siempre llueve. De la lluvia no se dispone a voluntad como 
de las aguas de regadío del mundo. Dios prueba con sequedades. "Esto es cosa muy acostumbrada de Dios y lo usa mucho con sus queridos" (567). "El espíritu irá y vendrá, y escondérseos ha Dios a ratos; pero por eso no habéis de aflojar, sino entonces buscarle más y trabajar por hallarle; que todo es por más merecimiento vuestro" (568); para que no crea que es fruto suyo y se ensoberbezca, sino que sepa que es obra de Dios, y se la agradezca, y así vaya ensanchando, cada vez más, su capacidad, esperándolo todo del cielo.

\section{e) Los tres votos religiosos: soli Deo}

Y ¿qué tiene que hacer para que esta lluvia de la gracia venga sobre su alma? Obedecer a Dios, cumplir sus mandamientos. Pero esto lo tienen que hacer también los seglares. La obediencia del religioso a Dios tiene que ser mucho más radical; tiene que seguir el camino de la perfección, el del pueblo escogido; cumplir los preceptos de Dios y los consejos evangélicos.

En primer lugar, tiene que dejar todos sus bienes por el voto de pobreza. En segundo lugar, amar a Dios con todo el corazón,"no os empleando en otro servicio alguno interior de vuestro corazón ni en pensamientos que sean al contrario de vuestro hábito y de vuestro camino" (570); amarle con toda el alma,"ni consienta vuestra ánima al cuerpo ejercitarse en otro ejercicio ni servicio exterior que el de tu Dios, sino que el espíritu sea señor, y no dejéis a la sensualidad que sobrepuje al espíritu" $(I b$.). Solo Dios es señor del religioso; nadie puede compartir con él esa propiedad, ni externa ni internamente. Es el voto de castidad perfecta. (Soli Deo era el lema de la tradición monástica, y esta era la razón del celibato). Hay aquí materia de contienda para toda la vida, porque la carne desea contra el espíritu y este contra aquella. Hay que sujetar la carne, macerarla, matarla. Solo Dios, y nadie más que él, debe ocupar su alma, su alma entera.

"El sacrificio que el religioso ofrece a Dios debe ser total. En el Antiguo Testamento, al seglar se le permitía sacrificar animales, cortados rabo y orejas; al levita, no. El seglar puede dejar algo para el mundo; el religioso, no. Todo él tiene que sacrificarse. "El día que dividiereis vuestro corazón, daos por muerto para con Dios" (571). Dios quiere "el corazón entero y no dividido" (Ib.); que se queme todo en holocausto perfecto; "que todo se queme en ardor y fuego del amor de Dios y no quede nada" (571). Otro misterio aún encierra lo de permitírseles a los seglares cortar el rabo y las orejas del animal que se iba a sacrificar, pero no a los levitas. Porque "estas dos cosas habéis de sacrificar y hacer pricipalmente en la religión, que es la oreja, entendida por la obediencia, y por la cola la perseverancia del nunca cesar de 
todo emplearse en el servicio de Dios, no cesando en la mocedad por flojedad ni en la vejez por flaqueza o enfermedad que acuda" (572).

\section{f) La acción por necesidad de la caridad: las obras de misericordia}

Pero en este mundo hay inevitablemente hombres necesitados con necesidades corporales y espirituales. El religioso, en ocasiones, tendrá que atenderlas. "Y todo lo que hiciere por solo Dios, y a él dirigir todos sus pensamientos y hechos y obras, así sus pensamientos interiores del corazón como todas sus obras de caridad en sus prójimos. A él solo referirlo todo; como que no ha menester entender ni es obligado como el seglar a entender en cosa del mundo, sino todo por Dios, sin discrepar un punto; que os obligáis a más que el seglar" (571). Tiene que cortar todos los afectos con las criaturas, también con las que viven en el monasterio. Soli Deo exterior e interiormente, en deseos, pensamientos, obras, conversaciones..., sin desviarse un punto de él, sin que ni siquiera la sombra de una criatura roce el cristal puro de su alma. Siempre que tenga que tratar con el prójimo, lo hará por Dios, enderezando a él la obra y el pensamiento, y por mandato de la obediencia. Las obras de misericordia con el prójimo se hacen, en realidad, a Dios.

\section{g) Las tres vías místicas}

Guardando todas estas cosas, Dios le dará “ la lluvia temprana con tiempo al principio de la entrada [...], haciéndoos nuevo hombre y desechando ese hombre viejo [...], no pensando ni obrando ni hablando sino de solo Dios, desechando del todo las pláticas viejas ociosas" ( $I b$.). Con esta lluvia temprana se lava el pecador de las aguas hediondas de Egipto. Son "aquellas primeras lágrimas amargas con que se lava de lo cometido y procura la enmienda" (573). Es el tiempo de la purificación, de la vía purgativa, necesaria para seguir adelante. "De aquí es que hay tantos en las religiones que no han aprovechado, porque nunca supieron de bien mandar [pedir] y buscar estas aguas tempranas" (Ib.).

Purificado, pasará a la vía iluminativa, y alcanzará "la otra lluvia de más dulzor, la lluvia serótina, la postrera y tardía, con que madura el grano y da fruto" ( $I b$.$) ; y sus lágrimas serán ahora "dulces más que el panal de la miel"$ (574). Con esta lluvia, se le irán pegando las gracias que trae el pan de vida comido diariamente y le irá embriagando "el vino de altísimas dulzuras de la vida contemplativa, [que le sacará fuera de sí y le meterá en Dios]. Este es el 
óleo de gran alegría que hace que el siervo de Dios no se dé a otras cosas sino a las de Dios [...]. Y haciendo esto no solamente os ayudaréis a vos, pero a otros siervos de Dios, mostrándoles el camino" (574-575).

\section{h) La convivencia en la comunidad religiosa}

Salida de Egipto o huida del mundo, entrada en el monasterio, vida activa y vida contemplativa, aspereza de la vida religiosa, necesidad de la gracia, guarda de los mandamientos, los tres votos religiosos, soli Deo, perseverancia, las obras de misericordia o caridad, vías místicas. Tales son los temas que ha de meditar el novicio para ser buen religioso. ¿Nada más? Nada. ¡Increíble! Porque este novicio no es un ermitaño, aunque pertenezca a los ermitaños de san Agustín. No va a vivir solo. Vive en comunidad, y profesará vida comunitaria. ¿Dónde quedan las relaciones con sus hermanos de Orden? ¿Dónde queda, en este aspecto, el Evangelio? Sólo en un brevísimo apunte: "amarás a tu prójimo como a ti mismo", obligatorio a todos los cristianos. ¡Inexplicable! Inexplicable para nosotros, pero no para ellos, que partían de una evidencia: el religioso se perfecciona en la soledad con Dios. Ahí y nada más que ahí. De ella sólo debe salir por caridad, por necesidad de la caridad, porque la obediencia se lo manda, como veremos detenidamente al estudiar al beato Orozco. No hay más relaciones lícitas con el prójimo que las obras de caridad o misericordia, espirituales y corporales. Tales obras son un honor que hacemos a Dios en el prójimo.

\section{6.- AYER Y HOY}

He resumido por extenso la plática, casi con sus palabras y con abundantes citas textuales. Porque es un buen compendio de la doctrina sobre la vida religiosa , tal como se la entendía en el siglo XVI; porque su autor es un hombre eminente, sabio y santo, distinguido por su preocupación por la salvación de las almas, que así se decía, y su espíritu limosnero, es decir, por su caridad, por las obras de misericordia corporales y espirituales. Es evidente que el tratamiento que hace de estos temas queda muy distante del actual; que es otro el punto de vista y otro el lenguaje empleado. Entre su pensamiento y el nuestro hay distancias insalvables. Su falta de atención a las relaciones fraternas, a las personas en sus relaciones cotidianas, es absoluta ${ }^{14}$. El religioso debe

14. Otro gran tema ausente en la Plática es el de la vocación. 
estar con Dios, con él solo, solus cum solo. Este es su oficio; en esto consiste su perfección. Todo lo que le distraiga de esa ocupación debe evitarlo. Todo religioso, también el que vive con otros en un monasterio, es un ermitaño. $\mathrm{Su}$ ermita es la celda. Esta debe ser su morada.

\section{7.- OTROS ESCRITOS}

La lectura de sus sermones más directamente relacionados con la vida religiosa confirma lo que acabo de decir. A san Agustín le dedicó cuatro. Ni una palabra en ellos sobre la vida comun. No se olvidó, en cambio, de consignar que fue ermitaño, fundador de ermitaños, orden a la que él pertenece, y de los Canónigos Regulares, tal como se creía en su tiempo'15.

\section{BEATO ALONSO DE OROZCO}

\section{8.- DOS HOMBRES, DOS ESTILOS}

El beato Orozco fue un gran propagandista religioso del siglo XVI; un tratadista completo de la vida cristiana. De sus obras se puede extraer un ejemplar perfecto del modelo mental que regía aquellas vidas. De la vida religiosa trata ampliamente todos los aspectos. Es un buen autor, el mejor junto a fray Luis de Granada, para conocer el conjunto de valores y contravalores de aquel siglo, en el que la religión lo invadía todo y todo lo dominaba. Un hombre del siglo XVI con mentalidad medieval, como en general los espirituales del Siglo de Oro; fruto tardío de movimientos similares europeos, aunque algunos de ellos harán innovaciones que marcarán los nuevos tiempos (san Igancio de Loyola, por ejemplo). Como otras muestras de nuestra cultura, según expuso Menéndez Pidal16. Su prosa es sencilla, elegante en su sobriedad. Es la plática de un predicador de reyes y plebeyos (fue predicador de Felipe II, pero también de los barrios de Madrid y sus aledaños); de nobles y villanos; de las gentes que frecuentaban la iglesia agustiniana del convento de san Felipe el Real17. Estilo familiar, claro, accesible a todos; estilo como de

15. In festo sancti Augustini, Patris Nostri, Concio I, 7, en DIVI THOMAE A VILLANOVA Opera omnia, Manilae 1884, 271

16. Ramón MENÉNDEZ PIDAL, Los españoles en la historia, ensayo introductorio de Diego Catalán (Selecciones Austral 101), Espasa.Calpe, Madrid 1982, 95-97.

17. El convento estaba sito en el $n^{\circ} 1$ de la Calla Mayor: Las gradas de la entrada a la iglesia, las gradas de san Felipe, eran famosas en la época como lonja de bulos y chismorreos. 
quien habla, pero el que habla es una persona culta, que conoce los aliños retóricos, aunque los use parcamente. Estilo funcional, sin entresijos ni profundidades. Por el número y la amplitud de los temas tratados, es el que mejor nos puede ayudar a formarnos una idea de lo que para ellos era la convivencia.

Camino muy distinto es el que hizo fray Luis de León, "el cual camino quise yo abrir"18 Fray Luis escribe con plena lucidez de lo que quiere hacer. Elige sabiamente las palabras, las concierta, les da tono y gravedad. Escribe como "los sabios y elocuentes pasados"19 para los sabios y elocuentes presentes, logrando la mejor prosa del siglo XVI y una de las mejores de todos los tiempos. Ni por lo que se propusieron hacer, ni por lo que hicieron, ni por sus conocimientos bíblicos y jurídicos, ni por la ciencia y dominio del lenguaje, ni por la sabiduría poética, ni por los lectores a los que se dirigieron, ni por la audacia en el pensar, ni por el carácter son comparables (lo cual no es obstáculo para que en las obras de fray Luis se detecten algunas influencias del beato).

Dejemos a cada uno en su sitio. Fray Luis está en la cima, grande entre los grandes. Está al alcance de todos comprobarlo. No hay más que leer el Memorial del amor santo de Orozco, un tratado sobre los nombres de Cristo, y De los nombres de Cristo de fray Luis. Algunos de los nombres coinciden en ambos obras. Es en ellos donde mejor se pueden advertir las diferencias. $\mathrm{Y}$ es también en ellos donde puede comprobarse que el famoso Opúsculo nada tiene que ver con el beato y sí mucho con fray Luis. ¡Como que es suyo! Un solo detalle: compárense los textos bíblicos que citan y, muy especialmente, su traducción. El estilo arcaizante con que está hecha lleva la marca de la casa de fray Luis. El Opúsculo es un primer borrador de fray Luis; unas notas, algunas apenas apuntadas, cuyo mejor destino debería haber sido la papelera. Notas que nada tienen que ver con el papel que aparece en De los nombres de Cristo, hijo de la ficción, como los personajes, el lugar y el tiempo en que ocurren los diálogos, datos todos que pertenecen a la técnica del díalogo renacentista. Los tres personajes no son sino los tres Luises: el biblista Marcelo, en el que él más se reconocía, pues era su vocación, el teólogo Juliano y el poeta Sabino.

Allí acudían desocupados y gentes de guerra a esperar y comentar las noticias que traía el correo que se apeaba en la casa del Conde de Oñate, en la acera de enfrente. "Adiós, de san Felipe el gran paseo, / donde si baja o sube el Turco galgo / como en gaceta de Venecia leo" (Miguel de CERVANTES SAAVEDRA, Viaje del Parnaso, I, vv. 127-129, edición y comentarios de Miguel Herrero García, (Clásicos Hispánicos. Serie IV, vol V)), CSIC, Instituto "Miguel de Cervantes", Madrid 1983, 220. Véase en las pp. 384-386 el comentario a estos versos.

18. De los nombres de Cristo, 1.3, Dedicatoria, en Obras completas castellanas, edic. cit., 658. 19. Íb., ib. 


\section{9.- PRINCIPIOS DOCTRINALES}

\section{a) Huida del mundo}

La huida del mundo o fuga mundi es una de las constantes en la doctrina de los maestros espirituales del pasado. Quien llega al monasterio lo hace huyendo del mundo. A él se acoge, como el náufrago a su roca de salvación. Pero allí le dicen que no se equivoque. El monasterio es roca de salvación, sí, y el mundo, lo que queda fuera, mar alborotado y traidor. Pero ese mar lo lleva consigo el fugitivo; su misma carne es también mar. Tendrá que huir de sí mismo, sofrenar su propio mar.

"Vos no os confiéis de vos; retraeos en vuestro monasterio; huid de conversaciones peligrosas; huid de todos y huid de vos mismo. Azucena es entre espinas el alma pura y casta y entre espinas se ha de guardar y fortalecer con ayunos, con disciplinas, con guardar los sentidos todos, con estar en continua clausura y con jamás aflojar en la oración [...]. Sepa el que ha de ser casto que ha de circuncidar todo lo superfluo, el comer demasiado, el dormir sin tasa, la soltura de los sentidos, la libertad en las salidas del monasterio, no siendo mandado. Todo se ha de evitar para que la castidad, azucena delicada, no reciba perjuicio"20

Huir del mundo, dejar el mundo, despreciar el mundo (Contemptus mundi se titulaba entonces el libro después conocido como Imitación de Cristo), apartarse del mundo, romper con el mundo, salir del mundo, salir de Egipto, morir al mundo, despojarse o desnudarse de las criaturas, desasirse, vaciarse de ellas, enajenarse o alienarse, anihilarse, desencarnarse... Son todas expresiones sinónimas de una misma realidad, cada una con sus matices peculiares. No voy a detenerme en su estudio, como no me detendré en ninguno de los otros temas que nos saldrán al paso. Cada uno de ellos será un son de trompeta, no más, alrededor del que nos ocupa: la convivencia. Hasta que este nos entregue sus secretos, y nos permita verlo desde su interior, revelándonos las razones en que se sustenta.

El cristiano, la doctrina es general, tiene que huir del mundo, es decir, de los hombres y de sí mismo. Porque el mundo de que hablamos no son los minerales, ni las plantas, ni las aves, ni las estrellas. El mundo son los hombres, lo que en los hombres hay hecho por ellos, lo meramente humano, el

20. Desposorio espiritual, epistola a un religioso, II, 462. Mientras no indique otra cosa, cito por Obras del venerable siervo de Dios fray ALONSO DE OROZCO, Madrid 1736. Cito el capítulo, cuando lo hay, en numeros arábigos; el tomo de las Obras en el que está la que se cita en números romanos y la página en números arábigos Siempre que no diga de quién es una cita es del beato. 
pecado. Hay que huir del mundo. ¿Hacia dónde? Hacia el interior del hombre; hacia lo que de Dios hay en él, hacia la imagen de Dios impresa en él, pero limpia del pecado; hacia la gracia que Dios le ha dado. Huir al interior, levantarse sobre sí mismo y refugiarse en Dios.

"Recibe, te suplico, a tu fugitivo [...]. Recíbeme, pues, siervo tuyo, vengo huyendo de las criaturas, que me recibieron, no perteneciéndoles, cuando huía de ti"'21."Recíbeme en tu cumbre, / recíbeme, que huyo, perseguido, / la errada muchedumbre"22.

\section{b) Fuera del claustro no hay salvación}

Todos los cristianos están llamados a la santidad. El Epistolario cristiano del beato, con cartas para todos los estados, es una buena prueba de ello. ¿Cómo podría ser de otro modo si los distintos estados y oficios, jerárquicamente ordenados, son todos, según se decía, de origen divino? Pero todos tienen que despreciar el mundo, huir afectivamente de él, refugiarse en su interior, salir de sí mismos hacia Dios, consagrados como están a él por el bautismo. Conseguir esto en el siglo es muy difícil, aunque no imposible, porque "con Dios todo es posible" (Mc 10, 27). Pero hay un camino que allana esta dificultad: huir efectivamente del mundo, salir de él y refugiarse en un monasterio, enclaustrarse de por vida, sepultarse en él, atado de pies y manos por los tres votos religiosos y las observancias monásticas. El religioso se pone realmente en camino de salvación, en estado de perfección.

¡La salvación! Este era el gran torcedor de las almas, el problema que las angustiaba. ¿Cómo encontrar seguridad ante la muerte? Los protestantes la encontraron en la justificación por la fe. Los católicos, en la pertenencia a la Iglesia; en creer lo que ella cree; en confesarse al sacerdote cuando se ha pecado (desde el pecado de Adán, todo hombre peca como todo hombre muere); en expiar los pecados con obras buenas, meritorias; en recogerse, como en puerto seguro, en algún monasterio, o en asegurarse las oraciones de los consagrados a Dios 23 .

Todo el que quiera alcanzar la salvación viviendo en el mundo tendrá que acercarse todo lo posible a los religiosos, a su forma de vida; calcar su vida en la de ellos. $\mathrm{O}$, al menos, entrar en relación con ellos mediante limosnas y

21. San AGUSTÍN, Soliloquios, I, 5.

22. Fray Luis de LEÓN, Poesías, XV, 16-18, en Obras Completas Castellanas, edic cit., 1457.

23. Cf. Lucien FEBVRE, Una cuestión mal planteada: los origenes de la Reforma francesa y el problema de las causas de la Reforma, en Erasmo, la Contrarreforma y el espiritu moderno, Ediciones Martínez Roca, Barcelona 1970, 13-83, en especial 63-71. 
donaciones para que recen por él en esta vida y, una vez muerto, ofrezcan sufragios por su alma24. Desde los primeros siglos medievales, se clasificó la sociedad en tres órdenes o estados. Los clérigos, muy especialmente los monjes, eran oratores, los hombres de oración (los otros dos órdenes o estados eran bellatores, los hombres de guerra, y laboratores, los hombres de trabajo). Los monjes eran "los profesionales de la intercesión [...]. En su reducto del claustrum, los monjes trabajaban poco, leían algo y oraban mucho [...]. Cumplían simplemente con su deber al pasarse en el coro horas y más horas del día y buena parte de la noche. Oraban [...]. El monje no oraba simplemente por orar: oraba por los demás. Intercedía. Su vocación específica consistía en interceder. El deber de interceder pertenecía al ideal monástico desde los tiempos más primitivos [...]. Los monasterios son, ante todo, verdaderas ciudadelas de oración, baluartes que defienden al pueblo cristiano [...]. La sociedad, la alta sociedad, hizo que dedicaran su vida a la alabanza de Dios por los que no le alababan y, sobre todo, a interceder por sus bienhechosres"25. Se entra en el monasterio para salvarse, pero también para rezar y hacer penitencia por los que quedan fuera: para que, también a ellos, se les abran los ojos, y comprendan la vanidad del mundo, indigno del amor del hombre. Los monjes abandonan sus bienes y siguen al Señor, pero necesitan que el pueblo los aprovisione. "A este ejército cristiano se subordina, en virtud del intercambio de la caridad, la multitud que le abastece, stipendiaria multitudo; a la que, al fin de los tiempos, se le dirá: tuve hambre, y me disteis de comer (Mt 25, 35)"26.

Es verdad que cada uno se santifica en su estado, pero el modelo de santidad, el único, es el monástico: huir de los hombres y refugiarse en Dios; salir de sí mismo, desnudarse de todas las criaturas, vivir en soledad con Dios. Al Todo se llega únicamente a través de la nada. Conforme a este modelo, cada uno tendrá que dar cuenta de su vida según su estado . Nunca se dijo expresamente que fuera del claustro no hay salvación; pero esto es lo que se con-

24. La bibliografía sobre testamentos, limosnas, mandas y fundaciones pías, hecho todo con el fin de que los beneficiarios rezasen por el ánima del donante, es abrumadora. Citaré solo, por reciente, a Máximo GARCÍA FERNANDEZ, Los castellanos y la muerte, Junta de Castilla y León, Valladolid 1996, y a Julio CARO BAROJA, por su conocimiento exhaustivo de los textos de la época, Las formas complejas de la vida religiosa (Religión, sociedad y carácter en la España de los siglos XVI y XVII), Akal Editor; Madrid 1978, 363-413 y 445-462. Pero no todo eran consideraciones piadosas. Había también sátiras, cuentos y chascarrillos sobre el particular. Había un epigrama que decía: "el señor don Juan de Robles, / con caridad sin igual, / hizo este santo hospital. ' Y también hizo a los pobres".

25. García M. COLOMBÁS, La tradición benedictina III. Los siglos VIII-XI. Ediciones

Monte Casino, Zamora 1991, 171-174, III.

26. San AGUSTíN, Contra Fausto, V, 9. 
cluye de las enseñanzas que se daban desde los tiempos primeros del monacato27. Santa Teresa de Jesús se esforzaba a sí misma a ser monja "con esta razón: que los trabajos y pena de ser monja no podía ser mayor que la del purgatorio, y que yo había bien merecido el infierno, que no era mucho estar lo que viviese como en purgatorio, y que después me iría derecha a el cielo, que este era mi deseo"28. Está claro: del mundo se va al infierno; del convento, que es como un purgatorio, derechitos al cielo."Sabe muy bien el ánima que ama a Dios, que como el pez vive en el agua escondido, así el corazón humilde tiene paz y gran seguridad en el encerramiento y donde nadie o cuasi nadie le mira"29.La invitación de Cristo a vender todos los bienes y seguirle (Mt 19,21) “a .todos los padres de Órdenes bastó a persuadir que renunciasen lo que tenían y que se encerrasen en los monasterios" 30 .

\section{c) Consagrarse a Dios}

Se huye del mundo, que es el pecado, al monasterio. ¿Para qué? No para meter el mundo en el monasterio, sino para dedicarse o consagrarse enteramente a Dios, sólo a él. Dios llena el alma del monje. También debe llenar la del cristiano; por eso es tan difícil ser santo en el siglo. Ni un rincón, por pequeño que sea, debe reservarse para sí el religioso. Hacerlo sería asegurarse un criadero de gusarapos, que terminaría por invadirle completamente; negar de hecho lo que profesó de palabra. Comprender esto es comprender la entrega absoluta de estos hombres a la mortificación de la carne y guarda de los sentidos; su rendimiento incondicional al parecer del superior, voz de Dios, anticipándose incluso a sus deseos para ahorrarle el trabajo de mandar; su asiduidad en la oración; su quedarse en alta contemplación, olvidados de todo y de todos, también de sí mismos; su encerrarse en un mutismo de por vida, tan sólo roto, los que lo rompían, por necesidad de la caridad, para hablar de Dios. Comprenderlo es comprender unas vidas que de otro modo nos resultan extrañas, disparatadas.

27. Cf. Michel GRANDJEAN, Hors du cloitre pas du salut? Notes sur l'ecclésiologie d'Anselme de Cantorbery et de son milieu, en Études Theologiques et Religieuses 70 (1995) 349. 357.

28. Vida, 3, 6. El otro gran motivo vocacional era el hambre."Se ha de mirar qué intento tiene la que entra, no sea solo por remediarse (como acaecerá a muchas)" Id., Camino, códice de Valladolid, 14, 1.

29. Epistolario cristiano, 2, I, 25.

30. Epistolario cristiano, 5, I, 97. 


\section{d) Negación del hombre}

Hay que huir del mundo al monasterio para vivir en soledad con Dios, consagrados a él, solo a él. Pero ¿por qué para vivir con Dios hay que huir de los hombres y encerrarse en soledad? Este es el problema.

Las palabras no viven aisladas; están entretejidas unas con otras, y. sus relaciones son sus significados. Decir una palabra es decir todo el sistema del que forma parte. Si no se tiene esto en cuenta, se desvaría. Leemos "Dios", y ponemos en la palabra nuestro significado. En vez de ir nosotros a los textos y averiguar el significado que en ellos tiene, traemos los textos a nuestra mentalidad, y los repetimos sin ton ni son, haciéndoles decir lo que no dicen.

Dios para ellos es alguien que está lejos de los hombres porque los hombres se alejan de él. Por el pecado, por el pecado original y los pecados personales, se van a una "región lejana", repetían con la parábola del hijo pródigo (Lc 15,13). ¿Adónde? A sí mismos, a los hombres. Añádase la visión neoplatónica del hombre. El alma cayó en la materia, último grado del ser, donde gime prisionera. Para ver a Dios tiene que purificarse, romper los grillos, desencarnarse. "¿Qué tiene de maravilloso que me dejara llevar de las vanidades y me alejara de ti, Dios mío [...].Pues ahora sacarás de este espantoso abismo al alma que te busca y ansía tus deleites [...]. Lejos está de tu rostro quien anda en un afecto tenebroso. No es con los pies ni recorriendo como se aleja uno de ti o se vuelve a ti" 31

Lo humano, lo que el hombre hace por su cuenta, sin la gracia de Dios, carece de todo valor. Para vivir con Dios tiene el hombre que salir de los demás y de sí mismo. A Dios se le encuentra lejos de los hombres, en la negación de lo humano, en el aislamiento, en la soledad contemplativa. Aquí radican las enseñanzas de san Juan de la Cruz sobre la nada como camino para llegar al Todo. Sólo el alma que, tras volverse a sí misma y negarse, vaciándose de toda criatura, también de sí misma, se lanza en vuelo raudo hacia las alturas, hasta el cielo empíreo, logrará darle alcance. "Volé tan alto, tan alto,/ que le di a la caza alcance" (san Juan de la Cruz).

Es verdad que Dios se hizo hombre; pero fue precisamente para que nosotros dejemos de serlo; para sacarnos del lodazal en el que estamos hundidos 32; para que podamos volver a él, del que nunca debimos separarnos. El

31. San AGUSTÍN, Confesiones, I, 18, 28.

32. "Siendo Hijo de Dios, vino a hacerse hijo de hombre para darnos a los que éramos hijos de hombre ser hijos de Dios" (San Agustin, Cartas, 140,4,10). Cristo "tomó la carne para que no te adhieras a lo carnal, y aceptó todo lo que tu madre te echa en cara (el llevarte en su vientre, los dolores del parto, las fatigas de la educación ) para que tu no te impliques en ello". (Id., íb., 243, 8). El texto más citado a este respecto es el de San CIRILO DE ALEJANDRIA:"Dios se hizo hombre para que el hombre se hiciera Dios" (Rom. hom., 9,3). 
se encarnó para que nosotros nos desencarnemos; se hizo criatura para que nosotros huyamos de ellas. El hombre se hace dios huyendo de los hombres. "El hombre divino y muy dado a Dios deja toda compañía y conversación con los hombres" 33

\section{e) Los valores humanos}

¿Dignidad del hombre? No; miseria del hombre. El hombre se hace digno solo cuando se convierte a Dios y se deshumaniza. La gracia de Dios, al hacerle hijo suyo, es la que le hace digno, restaurando aquella primera imagen impresa en él, desdibujada por el pecado.

Hay que vivir, decían, vueltos a Dios; desde Dios y cara a Dios. La ética aristotélica habla de virtudes; pero san Agustín es tajante y con él toda la tradición espiritual de Occidente: esas virtudes son, en realidad, vicios, y no sirven de nada. "Similitudes de virtudes" las llama con san Agustín el beato Orozco. El hombre tiene que "negarse a sí mismo", dice el Evangelio (Mt 16, 24 par); negar su condición humana, interpretaban los espirituales; despojarse de todo afecto humano, de su querer y parecer; del pecado, en suma, para descubrir su condición divina; hacer que desaparezca en él todo lo humano, abrasado por el amor de Dios.

"De nada les sirven a los paganos y judíos, que no creen en Cristo, ni a los herejes y cismáticos, que no tienen fe ni caridad ni sobria santidad, las obras de misericordia" 34 . Todos, pues, al imfierno, que fuera de la Iglesia no hay salvación. Algunas de las obras de misericordia las hacen hasta los más malvados de los hombres ${ }^{35}$. “ ¡Cuán estériles son sin caridad [las virtudes morales] y cuán feas delante de Dios. Pues nuestro padre san Agustín dice que en los filosófos no fueron virtudes, sino similitud de virtudes, porque les falta el amor. Considerad las virtudes teologales, fe, esperanza y caridad, cómo son de ningún valor, si les falta el lustre y vida de amor. San Pablo dice que ni la profecía ni las grandes limosnas ni los grandes tormentos valen nada sin el precio de amor (1 cor 13,1-3), el cual a todo da hermosura, a todo precio, y, siendo en sí pequeña la obra, la hace grande el santo amor"36. "Que esos bárbaros y gentes sin Dios, hombres infieles, no sepan amarse no me maravillo, pues no conocen a Jesucristo y son para tizones del infierno"37. Porque se aman con amor natural y no divino.

33. Instrucción de religiosos, Sevilla 1551, 7,64. Citaré siempre por esta edición.

34. San AGUSTIN, La Trinidad, XII, 7, 11.

35. Cf. Id.: El espíritu y la letra, 28.

36. Exercitatorio espiritual, lección $2^{\text {a }}$, II, 413.

37. Arte de amar a Dios y al prójimo, 13, I, 246. 
Hay que someter el cuerpo al alma y las pasiones a la razón, dijeron los filosófos; pero si el alma y la razón, arguye san Agustín, no se someten al Dios verdadero, que únicamente por las Sagradas Escrituras puede ser conocido, ese dominio no es recto. No están sometidas a Dios, luego lo están al demonio. No hay otra alternativa. "Luego las mismas virtudes que estos hombres creen tener, con las que dominan el cuerpo y las pasiones para conseguir algo o retenerlo, sin referirlas a Dios, son más bien vicios que virtudes. Aunque algunos las tengan por verdaderas y nobles, como están referidas a ellas mismas, y no se desean por algo superior, incluso en este caso son fatuas y soberbias. Por tanto, no se las puede considerar virtudes, sino vicios. El cuerpo no vive por sí mismo, sino por algo superior. Así lo que hace al hombre feliz no procede del hombre, sino de alguien que está por encima del hombre"38.

¿Se podrá llamar humanistas a estos hombres por mucho latín y griego que algunos de ellos supieran? Habrá que andar con cuidado, no sea que de ese significado pasemos al de afirmación de lo humano, lo que estaría en contra de toda su doctrina. Y si afirmamos lo humano, como debemos afirmarlo, no citemos sin ton ni son a los autores del pasado, obligándolos a dcir ló que no dijeron. Recordemos, agradecidos, sus nombres; estudiemos sus obras, pero a cada cual lo suyo.

\section{f) A solas con Dios solo}

Pensar en Dios, desear a Dios, hablar con Dios, contemplar a Dios. Esta es la única ocupación del buen religioso. Cualquier otra, si por necesidad de la caridad tiene que atenderla, le resulta desabrida y fatigosa. Por eso, en cuanto puede, la abandona para volver a su refugio contemplativo, del que, en realidad, no salió. Porque mientras hacía esa obra, su corazón seguía en Dios. Pues, como dijo san Agustín, y es un texto que recuerda repetidamente el beato Orozco, "te ama menos quien ama contigo algo que no ama por ti" 39 . En medio de la acción, por consiguiente, hay que mantener el corazón en Dios, sólo en él. El hombre no es dueño de sí mismo. No es dueño de sus pensamientos, ni de sus deseos, ni de sus acciones, ni de sus palabras. Todo esto le pertenece a Dios. Si no piensa en Dios, si no habla de Dios, si desea a alguien que no es Dios se está apropiando de lo que no es suyo. Textos, muchos textos, innumerables textos sobre la soledad. No es este el tema de mi estudio. Recogeré, por ello, tan solo algunos, los suficientes para comprender lo que dice sobre la convivencia.

38. SAN AGUSTÍN, La ciudad de Dios, XIX, 25.

39. Confesiones, $\mathrm{X}, 29,4 \mathrm{O}$. 
"Ya te amo a ti solo; a ti solo sigo; a ti solo busco; estoy dispuesto a servirte a ti solo, porque justamente eres tú solo el Señor. Quiero ser propiedad tuya"40. "El amor de Dios toda el alma quiere por aposento; toda la casa y corazón demanda, porque todo lo merece y todo lo quiere llenar del licor de su suavidad"41. "Bienaventurado el religioso que todos sus pensamientos y todos sus deseos pone en el altar de Dios y los inflama con el fuego del amor divino"42. "¡Qué vacío quiere Cristo nuestro corazón de todo amor terreno y cuán desocupado quiere que esté el religioso de todo negocio temporal"43. "Al hombre exterior y al hombre interior quiere el que todo lo crió para su servicio u honra. De aquí es que las vírgenes que para servir a Dios usaron los cinco sentidos del alma y también los cinco corporales y se emplearon en servicio de su criador, que tengan nombre de prudentes y sabias; [mientras las locas] anduvieron distraídas en las cosas temporales y perecederas" 44 . "No eres tuyo, hermano mío cristiano, ajeno eres y dueño tienes; $y$, porque no eres tuyo, no puedes pensar lo que tú quisieres, sino lo que quiere aquel gran Señor de todo el mundo, Cristo Jesús. [Los señores se conforman con que el esclavo haga lo que le mandan; no entran en interioridades.] Solo aquel absoluto Señor tiene jurisdicción sobre los deseos del alma. Estemos, pues, entendidos de que no somos nuestros aun para el pensamiento y por tanto le quiere Dios para sí. Tampoco somos nuestros para hablar [...]. No solamente tiene cuenta con las obras, mas aun con los pensamientos y palabras. En manera que no somos nuestros para pensar, hablar ni obrar lo que nuestra voluntad mala quiere [nuestra voluntad es siempre mala, si no se ajusta estrictamente a la de Dios, tal como está formulada por la Iglesia católica romana], sino lo que manda en su ley el que nos crió y compró para su servicio, Cristo, nuestrto Señor"45. "Mis ojos suyos son y él los manda; mi lengua y oídos él los posee y mis pensamientos y deseos más son suyos que míos. ¡Oh vida celestial! ¡Oh dichosa alma que tan alto ha subido"46. En este mismo sentido, escribe san Juan de la Cruz: "un solo pensamiento del hombre vale más que todo el mundo; por tanto, solo Dios es digno de él"47.

El tema aparece una y otra vez en sus escritos. En realidad no lo deja un instante, porque es el que alimenta su vida y la nutre. A solas con Dios solo,

40. Id., Soliloquios, I, 5.

41. Historia de la reina Sabá, 8, III, 300.

42. Epistolarios cristiano, 5, I, 92

43. $I b ., 98$.

44. Ib., 6, I, 121 .

45.Ib., 2, I, 28.

46. Arte de amar a Dios y al prójimo, documento II, I, 261

47. Dichos de luz y amor, $\mathrm{n}^{\circ}$. 34 . 
como si no hubiera nadie más en el mundo48; absortos el uno en el otro como dos enamorados. Soli Deo, Solus cum solo, se decía. El alma y Dios, nadie más. "Solo Dios basta", dice una poesía de san Teresa, que aún sigue repitiéndose. Pero la vida de la santa deja claro con claridad meridiana que solo Dios no basta. Necesitamos a los demás y los demás nos necesitan. Y ¡con qué apego, a veces, los necesitó la santa!

"Mi amado es a quien solo ama mi alma y ella se empleará en su servicio. Yo le traeré en mis manos y en mis pensamientos escrito por continua memoria amorosa [...]. No pensaré cosa ni la hablaré ni pondré por obra, que no sea ordenada para su santo servicio y gloria"49. "Mi alma se ha empleado / y todo mi caudal en su servicio. / Ya no guardo ganado / ni ya tengo otro oficio, / que ya solo en amar es mi ejercicio"50. "Sírvete de todo, nada amando sino a tu Esposo, que, si mujer fuerte eres, en esto te has de mostrar animosa, en que nada de todo lo criado amas por afición alguna que se inquiete tu corazón. Porque cuando la afición de la criatura trae desasosiego, ya es señal que pregona guerra, pues se revuelve el agua clara de tus pensamientos reposados" 51 . Una centella abrasa un monte. "Así acaece a quien en poco estima enseñorear su propio corazón, no matando con presteza cualquiera centella de afición inquieta y desordenada. [Hay que morir por completo al mundo, despreciar las riquezas y los honores]; mas menospreciar el cristiano amar otra cosa que a Dios y no querer ser de nadie amado, esta es cosa muy alta y no muchos han subido a tan gran homenaje. La razón es porque incluye un perfecto menosprecio de sí mismo, sin el cual el ánima no puede perfectamente amar a Dios. Ni se debe confiar alguno diciendo que su afición está bien empleada por las virtudes y bondades de otra persona, porque no es todo uno, ser buena alguna cosa y serlo para mí. [...No confiar] las riendas de la afición en otras manos sino en las de nuestro Dios, que solo es bastante para gobernar y dar quietud a nuestro inquieto y mal inclinado corazón, el cual pide este gran profeta Eliseo que sea vaso desocupado de toda afición para llenarlo de aceite claro, dulce y suave de su purísimo amor [...]." 52 . "El hablar distrae, y el callar y obrar recoge y da fuerza al espíritu [...]. Para guardar el espíritu no hay mejor remedio que cerrar los sentidos con uso e inclinación de soledad y olvido de

48. Este pensamiento, usual en los espirituales, aparece textualmente en san Juan de la Cruz (Dichos de luz y amor, $\mathrm{n}^{\circ}$. 143), y en santa Teresa de Jesús (Vida, 13, 9). Ibn 'Arabi de Murcia se lo aconseja a un novicio. A Leibniz le entusiasmaba. Cf. Miguel ASÍN PALACIOS, El Islam cristianizado, Editorial Hiperión, Madrid 1981, 173-174.

49. Epistolario Cristiano, 12, I, 202.

50. San JuAn de la CRUZ, Cántico $A 19$.

51. Memorial del amor santo, 14, II, 263.

52. Tratado del sacramento de la penitencia, 10, 1, 318-320 
toda criatura y de todos los acaecinientos, aunque se hunda el mundo. [ $E l$ alma que está ] advertida en Dios, luego con fuerza la tiran de dentro a callar y huir de cualquiera conversación; porque más quiere Dios que el alma se goce con él que con otra alguna criatura, por más aventajada que sea y por más al caso que le haga" 53

Abrahán, "confiado en la palabra del Señor rompió con todo y obedeció a la voz divina que le llamó. Bien pudiera el Señor hacerle las mercedes que le hizo sin sacarle de la casa de su padre y sin desterrarle de su patria y propia tierra. Mas porque el estilo de Dios es querer a solas el alma, pues las ocasiones y compañías malas, según la flaqueza humana, suelen ser parte, no solo para perder los gustos y regalos de Dios, sino aun para perder al mismo Dios; de aquí es que el Señor a los que mucho ama quiere desocasionarlos y apartarlos de todo peligro" 54

El alma que quiere amar a Dios tiene que romper con todo, salir de toda ocasión y peligro; romper con sus padres (sus lazos son los más peligrosos por ser de carne y sangre), con toda su familia y pueblo; negar su cuerpo, salir de él. Agustín, fugitivo en busca de Dios, deseaba "conocer únicamente a Dios y al alma. Nada más"55. Entendámonos: al alma, no como objeto de conocimiento científico, que eso sería vanidad, sino al alma en relación con Dios. A Dios y al alma. Ahora bien, decían ellos y en esto acertaban, esta verdad se descubre únicamente en la soledad, pensando en ella. Luego, concluían y en esto se equivocaban, Dios está en la soledad, y solo en la contemplación se le encuentra, y solo en ella se le ama. Solus cum Solo. Luego el hombre debe consagrarse, todo entero, a la contemplación. Solo en ella se santifica, porque solo en ella se hace uno con Dios. Para esto ha nacido y esta será su ocupación en el cielo por toda la eternidad.

"No fue cosa nueva llamar Dios a Abrahán, sacándole de la casa de su padre y desterrándole de su tierra. Cosa antigua es esta que Dios usó con aquellos que quiere su clemencia mejorar y particularmente enriquecer con sus misericordias. De lo dicho entenderá cada religioso la merced tan grande y favor tan insigne que le ha hecho nuestro Salvador Jesucristo en sacarle del siglo y apartarle de parientes y amigos, que muchas veces impiden el camino del cielo, tierra de promisión que mana leche y miel, para donde fuimos criados"56. "Oh religioso, mira que estás en el monte de la religión, apartado de

53. San JUAN DE LA CRUZ, Cartas, 8, en Vida y obras de san Juan de la Cruz, BAC, Madrid 1978, 10, 359-360.

54. Tratado de la suavidad de Dios, 34, II, 553.

55. Soliloquios, II,7

56. Tratado de la suavidad de Dios, 34, II, 553. 
los bullicios del mundo, solitario y bien acompañado con el Rey del cielo, Jesucristo; no te canses de trabajar y de ir adelante"57.

$\mathrm{Y}$ este debe ser también el programa de los que viven en el mundo. A su hermana casada le escribe: "cada noche, después que todos son recogidos, os retraigáis a vuestro oratorio para hacer cuenta con vuestra conciencia. Poco aprovecha tener gran casa, pues los otros la moran y pasean, si no tenéis, hermana, una celda con un oratorio que sea la casa de vuestra alma. Toda la casa os debe ser como el diluvio a la paloma, que en nada reposó hasta que vino al arca. Vuestra arca y reposo ha de ser un oratorio, adonde delante de un crucifijo os deis a Dios, rezando vuestras devociones, las que sin pesadumbre podáis llevar"'58.

Llamada a la santidad, santificación en el estado de casada; pero con el rigor y recogimiento de una monja, libre de todo afecto humano. Lo primero que tiene que hacer nada más levantarse es dar gracias a Dios y, a continuación, oír misa. Después llevar la casa con el pensamiento fijo en Dios; meditar la pasión del Señor, rezar los Salmos Penitenciales y el Oficio de Nuestra Señora con las Horas de la Cruz, si le queda tiempo. Por la noche, Completas y examen de conciencia. Sola con Dios solo, también ella. No hay más modelo de santidad que el monástico, el de la soledad en Dios. Dentro de él, a cada uno se le juzgará según su estado.

\section{g) Nuestra visión de la soledad y la convivencia}

Pero a nosotros no nos convencen estos razonamientos. El hombre es relación, reciprocidad, y sólo en la reciprocidad aparece y se realiza, si bien su verdad última es soledad. Sólo en esta puede percatarse de aquella su condición. Para darme cuenta de que dos y dos son cuatro, repite Ortega, necesito pensar yo, yo solo, en mi soledad, esta proposición. Soy radicalmente soledad, pero, con la misma radicalidad, soy compañía. Necesito soledad y necesito convivencia. El hombre se hace hombre entre hombres. Necesita nutrirse de sustancia humana, y solo en la convivencia puede absorberla. Y necesita soledad para hacer suyo este alimento, para hacerse a sí mismo, realidad única, auténtica, él mismo.

La soledad no es nunca absoluta. En mi soledad están siempre los otros. "La soledad es siempre soledad de alguien, es decir, que es un quedarse solo y un echar de menos", como dice Ortega59. "¡Qué solos se quedan los muer-

57. Ib., 556 .

58. Regla de vida cristiana, documento 6, II, 394-395.

59. El hombre y la gente (Col. Austral 1501), Espasa-Calpe. Madrid 1972, 46. 
tos!", escribió Bécquer. No; los muertos no se quedan solos. Somos nosotros los que nos quedamos solos de ellos. Por lo mismo, la soledad debe ser transitoria, no un estado de por vida. De nuestro refugio de soledad, en el que construimos nuestra persona en reflexión personalísima, tenemos que salir a los otros en busca de alimento humano, vivir como hombres, reciprocarnos unos a otros, que esto es ser hombre.

Convivencia y soledad, soledad y convivencia. Cuando la noria de la vida va de una a otra en continuo girar, brota el agua clara y jugosa que nos nutre, y florea, y nos colma de frutos que enriquecen la condición humana, y la iluminan. "La persona se $<<$ nutre $>>$ de personas; despliega su realidad al verterse efusivamente sobre otras; y cuando está en soledad -algo esencial e indispensable-, esto significa una retracción respecto a las otras personas, una soledad de ellas, en la cual siguen presentes"60.

Para los cristianos "Dios es amor". (1 Jn 4,8), amor encarnado; amor que se da a los hombres; amor que "se hizo hombre y acampó entre los hombres" (Jn 1,14); amor que sólo en las relaciones humanas puede ser amado, y de las que no se le puede separar ni siquiera cuando nos quedamos en soledad, pero que para ser vivido exige soledad, contemplación; frecuente, asidua contemplación.

Ni humana ni cristianamente es sostenible hoy el solus cum solo. ¿Es cristiano un Dios abismado en su soledad, ocupado exclusivamente del alma que, sola , se ocupa de él, como dice Bernardino de Laredo ${ }^{61}$ y demás autores espirituales? Los dos solos, nadie más. ¿Es cristiano este recogimiento? ¿Es cristiano interpretar la relación con Dios en términos de enamoración, de modo que ninguna otra persona pueda ocupar el pensamiento, y todo lo humano tenga que ser sacrificado como algo nefando? ¿No habrá que dejar de una vez este lenguaje tomado del Cantar de los cantares, en él muy justificado, puesto que son dos enamorados, y en qué grado y con qué belleza de expresión,

60. Julián MARÍAS, Mapa del mundo personal, Alianza Editorial, Madrid 1933, 195.

61. Cf. José VEGA, La vocación agustiniana. El proyecto filosófico-monástico-sacerdotal de san Agustín, Edit. Estudio Agustiniano, Valladolid 1987, 270-276. El texto de LAREDO dice: "el adorar a Dios en espíritu está en no solamente contemplarle puro espíritu como es, mas para le contemplar el vero contemplativo, dejarse de toda carne y de entendimiento de carne: ni con carne, ni de carne ni por carne; mas que el ánima puro espíritu, desnuda de todo cuanto en la tierra Dios crió, entienda en un solo Dios, desnudo de cuanto crió en el cielo y en la tierra; sino una sola a un solo, y que ella esté despojada aun de sí misma, y él, desnudo de todo cuanto crió. Así han de adorar los verdaderos adoradores" (Subida del monte Sión, en Misticos franciscanos españoles, BAC, Madrid 1948, II, 114-115). Laredo cita en confirmación de su doctrina el conocido texto de Jesús a la samaritana, Jn 4, 23-24, que dice excatamente lo.contrario. A Dios se le adora amando a los demás. Pero cada época tiene sus lentes para leer los textos, también los bíblicos. 
los que hablan? ¿No habrá que hablar más bien en términos de amor, lo cual es muy distinto? Lo comprenderemos mejor al estudiar a fray Luis de León y a Malón de Chaide, en los que nos volverá a salir el tema.

\section{h) Los tres votos religiosos}

Consagrarse a Dios, a él solo: tal es el fin de los votos religiosos. Por la pobreza se renuncia a los bienes externos; por la castidad, al cuerpo; por la obediencia, a la voluntad62. De esta hablaremos más adelante. De la pobreza, dado el tema que nos ocupa, y tal como lo plantea el beato, no hay por qué hablar.

"Excelente cosa es la castidad y pureza humana de las personas angélicas, con la cual, en el monasterio encerrada y como sepultada en vida, servís al Señor, tratando las cosas eternas y celestiales en vuestro corazón!"63. Como enseñó san Pablo, recuerda el beato, el casado está dividido (1 Cor 7, 33-34), "porque ya no tiene la libertad que antes tenía para vacar a la oración y levantar su corazón a Dios, como la tenía siendo soltero. Y de la mujer dice que no siendo casada piensa las cosas de Dios y cómo sirva al Señor; mas teniendo marido ha de tratar en su corazón cómo le dé contento". ${ }^{64} \mathrm{El}$ voto de castidad es "el primero que habilita al alma para más brevemente orar y contemplar vuestra bondad, poder y hermosura, renunciando por vuestro amor al deleite que suele hacer en alguna manera a los hombres semejantes a los brutos animales. No sé cosa alguna, dijo mi padre san Agustín, que tanto derribe el espiritu como el tocamiento de la mujer. Gran bien es la entereza [virginal] del alma para considerar suavemente las cosas eternas, olvidando todo deleite, y poner en esto gran solicitud, sin estar dividido el hombre en cuidado de la mujer, hijos y familia"65.

Tal es la razón del celibato. Desde antiguo, en las distintas religiones, lo sexual es una zona misteriosa, supeditada a influencias extrañas de dioses o demonios. Dedicarse al culto o a la caza o a la guerra, es decir, a actividades bajo la influencia de un dios concreto, exige renunciar a lo sexual, dominado por otro dios. "Exponerse a la inteferencia de zonas de soberanía divina es peligroso" 66 .

62. Cf. Desposorio espiritual, 1, II, 437-438.

63. Ib., 3, II, 443.

64. Tratado de la suavidad de Dios, 33, II, 552.

65. Libro de las confesiones, II, 9, III, 83; el texto de san Agustín en Soliloquios, I, 10, 17.

66. Elisabeth FRENZEL, Diccionario de motivos de la literatura universal, Edit. Gredos, Madrid 1980, s. v. voto de castidad. 


\section{i) Los celos de Dios y su venganza}

Consagrados a Dios, a él solo. Intentar alguna veleidad con las criaturas, admitir en el corazón algún afecto humano, es peligroso. La venganza de Dios será terrible. Es un amante celoso, el más celoso de todos, como corresponde a su santidad. Los maridos de la época solían ser expeditos; lo serán, sobre todo, años más tarde los calderonianos. Pues veamos cómo es el esposo divino pintado por el beato Orozco.

"Celoso es vuestro Esposo y cada palabra os cuenta y aun el alzar de ojos con curiosidad mira con aviso"67. Ni conversacioncillas ni pestañeos. Hay que tener en cuenta que este texto no se refiere solo a la castidad, sino a cualquier afecto humano. Fuera toda relación humana con las criaturas. "Como sea tan delicada la vista del alma para con Dios, también una afición desordenada, aunque pequeña, atormenta y oscurece la vida espiritual" 68 , y esto aunque sea sin mala intención. "Mirad, hermana, que se llama Dios, esposo vuestro, celoso en la Escritura, porque vela y cela en gran arte a sus esposas y las está mirando, según decía la esposa en los Cánticos, así como de ventana alta y como quien mira por reja, que ve a los que pasan por la calle y no es visto. Siempre mirad que os ve vuestro esposo en público y en secreto, a solas y acompañada. Por tanto, guardad con cuidado vuestro corazón, porque de él nace la vida espiritual o la muerte"69. Tema recurrente este del esposo que "está en atalaya, espiando en todo tiempo y lugar cómo le servimos y con qué solicitud le traemos sobre nuestro corazón, no amando otra cosa sino a él"70. "No se contenta el Señor, que es esposo muy celoso, que se le dé parte del tiempo orando, oyendo misa y sermón y dando limosnas, confesando y comulgando, obras excelentes y de gran valor; y que con esto se le den horas y tiempo a las vanidades, deleites feos y juegos desatinados"71. Dios exige todo el tiempo, todos los deseos, pensamientos, palabras y obras, toda la vida. Castiga sin piedad con todo género de desgracias a quienes no se la dan. El mal es el azote de que se sirve para escarmiento de pecadores y aviso de los justos, como ya dijo san Agustín. Tema este que nos llevaría demasiado lejos; quede tan solo apuntado.

67. Epistolario cristiano, 6, I, 123.

68. Tratado del sacramento de la penitencia, 10, I, 318. "Eso me da, escribe san Juan de la Cruz, que un ave esté asida a un hilo delgado que a un grueso, porque, aunque sea delgado, tan asida se estará a él como al grueso en tanto que no le quebrare para volar" (1 Subida del monte Carmelo, 11, 4, edic. cit., 479).

69. Desposorio espiritual, 4, II, 447.

70. Ib., 7, II, 454.

71. Arte de amar a Dios y al prójimo, 8, I, 236. 
¡Qué idea más pobre de Dios esta de tenerle por un enamorado celosísimo! Y lo grave es que no es peculiar del beato Orozco, sino de toda la tradición, con raíces en el Antiguo Testamento. El celoso es egoísta, insaciable, vengador. Para él no existe la persona, sino un objeto del que él es propietario. Lo acaricia o lo destruye. El solo hecho de imaginar que un rival se lo arrebate le angustia. Vive roído de sospechas, permanentemente inseguro de sí mismo ${ }^{72}$. Desechemos tal imagen de Dios por muy autorizada que esté. Es, en realidad, su negación. El Nuevo Testamento no la consiente. Dios no tiene a sus criaturas por rivales de su amor. No es celoso de que sus criaturas se amen. ¿Cómo va a serlo si es precisamente entonces cuando más fielmente son imagen suya?73

\section{j) La acción por necesidad de la caridad: Las obras de misericordia}

Solus cum Solo, Pero uno no está solo en la vida. "Cada uno es dos personas, particular y universal, pues es parte de la república de este universo"74. Ahí, se quiera o no, están los otros, y hay que contar con ellos. Son nuestros aliados o nuestros enemigos. Hay pobres y enfermos, ignorantes y pecadores, buenos y malos. Hay necesidades corporales y espirituales. Hay que atenderlas. Es lo cristiano. La redención tiene que llegar a todos; todos tienen que conocer la voluntad de Dios y seguirla, amarle a él, a él solo. Hay que dar de comer al hambriento, visitar a los enfermos, curarlos... Hay, pues, que practicar las obras de misericordia, relacionarse con el prójimo; pero hay que hacerlo solo por necesidad, por necesidad de la caridad, según la fórmula de san Agustín; porque lo exige el amor de Dios y amando en ellas a Dios. Por eso, para que tales obras no queden desvirtuadas el pensamiento tiene que seguir fijo en Dios; y se han de hacer, no por voluntad propia, sino por mandato del superior. Las obras de misericordia serán un breve paréntesis, pero hechas con la intensidad del amor de Dios. Se va a ellas desde la oración, y a la oración se vuelve desde ellas, sin dejar la oración mientras se hacen.

72. Cf. Carlos CASTILLA DEL PINO, Celos, locura, muerte, Ediciones Temas de Hoy 1995, 15-171; Algirdas J. GREIMAS y Jacques FONTANILLE, Semiótica de las pasiones, Siglo XXI Editores, Madrid 1994, 59-271.

73. PLATÓN escribió: "el hacedor [del cosmos] era bueno, y en cuanto bueno no nace en él ninguna clase de envidia respecto de nadie. Ajeno a la envidia, ha querido que todas las cosas naciesen semejantes a él lo más posible" (Timeo 29 d-e). Y ARISTÓTELES: "si tuviera algún sentido lo que dicen los poetas, y la divinidad fuese por naturaleza envidiosa [...]. Pero ni es posible que la divinidad sea envidiosa (sino que, según el refrán, mienten mucho los poetas)..." (Metafísica 983 a).

74. Epistolario cristiano, 12, I, 203. 
"No se sufre, alma mía, que te ocupes en cosas superfluas, si quieres perseverar en tan alto ejercicio y traer siempre en la memoria a tu amado Esposo, Cristo Jesús. Mas conviene que pases así, como quien va de camino por las criaturas, como quien toma lengua para hablar a su criador. [La esposa le halló después de haber rodeado la ciudad, las plazas y los barrios ], que significan los rodeos, anchuras y ocupaciones de esta vida, los cuales se deben dejar, pasando un poco adelante, $\mathrm{y}$ hallarás luego a quien buscas, o por mejor decir, a aquel de quien eres buscada, tu dulce amado Jesús [...]. Esta vida activa, alma mía, con que ordenas tu casa y tu familia, sirves los enfermos y pobres, y aun cumples en lo necesario contigo misma, escala es para la vida contemplativa"75.

Acción por necesidad de la caridad, pero con moderación. "Esta es tu casa [el corazón de Cristo, abierto por la lanza], en la cual te manda el Rey celestial que estés retraída el sábado, no entendiendo aun en guisar lo que has de comer, según estaba dicho de los hijos de Israel. Todo es sábado y fiesta muy solemne el tiempo que empleares en tan santa consideración, la cual debe ser tan desocupada de toda inquietud, que aun de lo que parece ser necesario se disminuya y modere" 76 .

.Estos hombres amaban la soledad, estar a solas con Dios solo. Salir de ella, incluso para obras de caridad, les resultaba enojoso. Se les oye gemir bajo la fatiga, divididos. Paciencia era la virtud que entonces practicaban. "Mano siniestra es la vida activa, bien llena de siniestros y trabajos, de los cuales Marta, turbada, se queja. Mas como sea mano del Esposo, Cristo, hase de llevar con paciencia, teniendo muy firme esperanza que nos abrazará con su mano derecha, que es la contemplación perfecta" 77 . Todo trato con las criaturas era para ellos un tormento. "También el amor santo del prójimo, cada día haciendo su oficio, hay ocasión de ejercitarle, que no es pequeña cruz para merecer el cielo"78. "Esta vida penosa es llena de cuidados y parte el corazón en diversas partes"79.

Al menos dos veces cita el beato la famosa norma de san Agustín sobre la vida contemplativa y activa: la contemplación se elige "por amor de la verdad"; la acción misaericordiosa se tolera "por necesidad de la caridad". Acción que no se elige por propia iniciativa, sino que se acepta cuando la impone el superior ${ }^{80}$.

75. Memorial del amor santo, 6, II, 186-187.

76. Íb., 32, II, 327.

77. Monte de contemplación, 13, II, 164.

78. Arte de amar a Dios y al prójimo, prólogo, I, 220.

79. Epístola a don Bernardino Pimentel, III, 460.

80. Cf. Epistolario cristiano, 2, I, 39; Tratado de la corona de Nuestra Señora, 12, párrafo 3, III, 177; san AGUSTÍN, La ciudad de Dios, XIX, 19; Id., Cartas, 48, 1-4; José VEGA, La 


\section{k) La contemplación de Dios, hábitat del alma}

Por eso, llevados de su querencia, volvían a su recogimiento contemplativo lo antes posible. En realidad, no habían salido de él. "A la tarde, dice san Juan de la Cruz, te examinarán en el amor. Aprende a amar como Dios quiere ser amado y deja tu condición"81. "No se ha de contentar el siervo de Dios de andar delante del Señor mortificado y compuesto solamente en el monasterio, coro y altar. Mayor recato y guarda es menester donde hay más peligro, donde las ocasiones se ofrecen a cada paso, y donde somos espectáculo de los ángeles y de los hombres. [Llevamos hábito distinto de los seglares.] La vestidura de penitencia ha de ser divisa de la que anda dentro del alma [...]. El algalia y el ámbar, adondequiera que están, en el arca, en casa o en la calle dan buen olor y en nada se mudan por mudar el lugar. Tal ha de ser el buen religioso adondequiera que se hallare, dando olor de virtud y de religión, despertando con palabras de espíritu y ejemplo santo a que los distraídos cristianos se recojan y los virtuosos pasen adelante perseverando en su vida cristiana [...]. Siempre es uno mismo en el monasterio y fuera de él. No se morirá como el pez, cuando le sacan del agua, porque consigo se lleva el estanque de santas aguas, deseos espirituales y consideraciones, no de la tierra, sino del cielo"82. La oración es como el cinamomo y el bálsamo. "Estos árboles, cinamo y mirra, dice el sabio que están en la plaza (Ecclo 24), porque los perfcctos oradores no tienen cierto lugar para orar por serles todo lugar oratorio. David dice que estando entre muchos loaba a su Criador. Quiere decir que todos los negocios del reino no eran bastantes para que su corazón saliese de la oración. En casa, en la calle, en la plaza, siempre ora el que está diestro en orar. Lenguaje es este que pocos le entienden, porque pocos lo alcanzan y menos lo procuran. Estos tales, de cada hormiga pequeña levantan oración y contemplación muy subida hasta llegar al Criador, que tan omnipotente, tan sabio y magnífico se manifiesta en sus criaturas" 83 . "No tienes excusa, alma, para no ejercitarte en este arte por decir ocupada estoy. No te vayas, alma mía, de ti misma, vagueando por los pensamientos, sin provecho, ni estés del todo atenta, cuando casi por fuerza, para cumplir con los otros, eres ocupada en conversación. Hurtar te puedes delante de todo el mundo y estar dentro de tu corazón, acompañando allí al bendito Esposo Jesús, aun en todo ejercicio corporal no superfluo"s4.

vocación agustiniana. El proyecto filosófico-monástico-sacerdotal de san Agustín, edic. cit., 301-334.

81. Dichos de luz y amor, $\mathrm{n}^{\circ} .59$.

82. Tratado de la suavidad de Dios, 34, II, 555.

83. Vergel de oración, 4, II, 13.

84. Memorial del amor santo, 6, II, 187. 


\section{1) Dos formas de vivir la relación con Dios: verticalidad y horizontalidad}

Estos hombres estaban volcados hacia Dios, hacia el cielo empíreo, morada de Dios y de sus santos. Este movimiento de entrega a Dios, este ímpetu hacia Dios, vaciándose de las criaturas, era la caridad. De allí, desde Dios, por necesidad, solo por necesidad del amor de Dios, bajaban hasta los hombres para vaciarlos, también a ellos, de todo amor terreno y llevarlos a Dios, al reposo recogido en Dios. La orientación de su vida era vertical.

La nuestra, en cambio, es horizontal. La sociedad secularizada habla de justicia y solidaridad, no de caridad, que regala, dicen, las migajas que se le caen de la mesa, y encima exige agradecimiento. Los cristianos hablan cada vez menos de caridad. Del lenguaje coloquial de la mayoría de ellos ya ha desaparecido. Se mantiene en círculos reducidos, muy profesionales y cerrados, y aun en estos su uso se va haciendo cada vez más raro. Varios diccionarios bíblicos ya no la registran, y otros que le dan entrada se limitan a remitir a otras palabras. De las traducciones bíblicas está desapareciendo. Hoy se prefiere la palabra amor.

"El amor que Dios nos tiene inunda nuestros corazones por el Espíritu Santo que nos ha dado" (Rom 5, 5). Este amor nos exige respuesta. "De su plenitud todos nosotros recibimos, ante todo un amor que responde a su amor" (Jn 1,16). Pero esta respuesta no consiste en devolver a Dios el amor que él nos ha dado, ¿para qué lo querría?, sino en darlo a los demás, continuando la dirección de Dios, entrando en su onda expansiva, entregándose a los otros. La dedicación o consagración del cristiano no es a Dios, sino a los hombres; porque participa de la entrega, dedicación o consagración de Dios a ellos, tal como se ha manifestado en Jesucristo; porque está identificado con el amor de Dios. Los cristianos no se consagran a Dios. Es Dios quien les consagra "para que os pongáis en camino y deis fruto, y un fruto que dure" (Jn $15,16)$.

"Os doy un mandamiento nuevo: que os améis unos a otros; igual que yo os he amado, amaos también entre vosotros. En esto conocerán que sois discípulos míos: en que os amáis unos a otros" (Jn 13,34-35). "Hemos comprendido lo que es el amor porque aquel se desprendió de su vida por nosotros; ahora también nosotros debemos desprendernos de la vida por nuestros hermanos" (1 Jn 3, 16). "Amigos míos, si Dios nos ha amado tanto, es deber nuestro amarnos unos a otros" (1 Jn 4,11)85.

85. Cf. José VEGA, ob. cit., 533-545; Id., Sobre el "amor mutuo" de los cristianos, en Estudio Agustiniano 31 (1996) 79-93. 
m) El orden de la caridad

Hay que mantener, pues, la caridad en todo tiempo y lugar, dentro y fuera del monasterio, en soledad con Dios y en el trato con los hombres. "Si queremos saber qué cosa es caridad consideremos que es un amor con el cual amamos a Dios por él mismo y al prójimo por Dios"86. Es la definición que dio san Agustín. "Llamo caridad al movimiento del alma que lleva a gozar de Dios por él mismo, y de uno mismo y del prójimo por Dios, y concupiscencia al que lleva a gozar de uno mismo, del prójimo y de cualquier cuerpo no por Dios"87. Todo lo demás, lo dice también san Agustín, es concupiscencia. Todo afecto humano, toda relación que se fundamente en motivos humanos, es concupiscencias8.

La caridad tiene un orden y hay que observarlo en toda relación humana. "Hay que amar a Dios porque es sumo bien y nos ha de hacer bienaventurados; amamos a nuestra ánima porque es capaz de bienaventuranza y amamos al prójimo por la misma razón; y finalmente hemos de amar nuestro cuerpo porque ha de comunicar de la gloria del alma, cuando resucite glorioso. Esta es la orden de la caridad"89. La doctrina se repite, y da lugar a una casuística compleja, en la que no voy a entrar, aunque algunos de sus flecos nos saldrán al desgaire.

Hay que amar a Dios por él mismo, por ser quien es ${ }^{90}$. Se le puede amar también por los beneficios naturales y de gracia que nos ha hecho y por el de gloria que nos hará; pero el amor más alto, el amor de amistad, es amarle por él mismo, "porque es bondad soberana, santidad eterna y sabiduría no limitada" 91 .

Todos los estados de la santa Iglesia romana (religiosos, sacerdotes, casados, solteros...) tienen obligación de amar a Dios"2. "Pero no se puede servir y amar a Dios sin Dios, sin su gracia y favor" 93 . Y hay que amarle ininterrumpidamente. "Este mandamiento grande del amor de Dios no es posible

86. Tratado de la suavidad de Dios, 12, II, 492.

87. La doctrina cristiana, III, 10, 16; cf., Id., La Trinidad, VIII, 7, 10.

88. Cf. José ORTEGA Y GASSET, Vives-Goethe (Col. El Arquero), Ediciones de la Revista de Occidente, Madrid 1973, $47-48$ y 77; Id., En torno a Galileo (Esquema de las crisis) (Col. Austral 1365), Espasa-Calpe, Madrid 1965, 178-187.

89. Arte de amar a Dios y al prójimo, 12, I, 244; ib., 13, 244.

90. Cf. Domingo NATAL, La mística agustiniana del amor en el beato Alonso de Orozco, en Estudio Agustiniano 26 (1991) 231-276; Ana J. BULOVAS, El amor divino en la obra del beato Alonso de Orozco, Fundación Universitaria Española, Madrid 1975.

91. Historia de la reina Sabá, 9, III, 302.

92. Cf. Epistolario cristiano, a su Alteza el Príncipe Nuestro Señor, I, sin paginación.

93. Arte de amar a Dios y al prójimo, prólogo, I, 219. 
cumplirle actualmente, siempre amando al Criador, porque esta perfecta manera de amar se guarda para la gloria"94. Aquí se le puede amar perfectamente acercándose lo más posible a la manera con que le aman los bienaventurados. Así le aman los religiosos, que, dejando toda otra ocupación, "se dan a la oración y contemplación con largas vigilias"95. Le ama todo cristiano (cristiano para el beato es sinónimo de católico, los otros son herejes) que, no estando en pecado mortal, cumple la ley de Dios, pero ya hemos visto que el reglamento de vida cristiana que da a los seglares está calcado sobre el de la vida religiosa.

Hay que amar al prójimo por Dios, por ser capaz de la bienaventuranza o para que lo sea; "por vía de compañía, que nos puede ser compañero en la gloria"96. Tal amor, el amor de caridad, único que merece la gloria, se recibe de Dios. Solo los que están en gracia aman a su prójimo. Luego fuera de la Iglesia católica no se ama al prójimo. Los valores humanos son una filfa. "No hay amor al prójimo sin amor de Dios" ${ }^{97}$. Es a Dios a quien se ama realmente en el prójimo. "Llamar nuestro Salvador al mandamiento del prójimo semejante al de Dios fue declararnos en cuánto tiene el Señor su imagen, pues quiere amando al Criador también amemos y honremos su imagen, que es el hombre. Y por que del retrato al retratado hay gran similitud dice ser muy semejante el un mandamiento al otro"98. Al prójimo se le ama por Dios, porque Dios lo ha mandado; se le ama en Dios, viviendo su misma vida, y para Dios, "para que goce de Dios"99. Al prójimo se le ama desde Dios, con Dios, en Dios, por Dios y para Dios. Son expresiones que aparecen constantemente en el beato Orozco y en los demás espirituales. Lo demás es amor natural, que nada vale; amor de gentiles, no de cristianos. Estos huyen del amor natural, como huyen del mundo y sus vanidades. Huyen de él, sobre todo, los religiosos.

Amar con amor cristiano "será tener la caridad tan mortificados los ojos en ver, los oídos en oír, la lengua en el hablar y las manos para obrar, que ya no son ojos nuestros, sino de Dios, que ve por ellos la necesidad del prójimo para remediarla; los oídos son del Criador no oyendo lisonjas de voluntad, no murmuraciones ni vanidades, sino el gemido del enfermo, la palabra divina, las alabanzas de Dios y Oficio Divino y todo aquello que es gloria de Dios. ¡Oh dichosos ojos por los cuales mira Cristo; bendita la lengua con la cual

94. Historia de la reina Sabá, 9, III, 305.

95. Ib., ib.

96. Arte de amar a Dios y al prójimo, 13, I, 246.

97. Epistolario cristiano, 1, I, 11.

98. Arte de amar a Dios y al prójimo, 11, I, 243.

99. Epistolario cristiano. 1, I, 10. 
habla el Señor; y bienaventurados los sentidos que son instrumento del Espíritu santo y no del demonio ni del pecado! [...]. Vivo ya yo no, vive en mí mi Redentor Jesucristo (Gál 2,20). Ya murió mi hombre viejo; toda mi ánima ama a Dios; suyos mis ojos, mis oídos y mi lengua"100.

En el que ama así a su prójimo, es en realidad Dios quien en él ama a Dios en el prójimo. Este tal ama con amor espiritual y no carnal101; ama lo común, lo que permanece, y no lo particular y transitorio'102. Los que así se aman tienen un alma sola y un solo corazón en Dios ${ }^{103}$ y "honran mutuamente a Dios, unos en otros"104. Porque, en efecto, las obras de misericordia con el prójimo son honores que se hacen a Dios, honores "al mismo Dios [que] se ha hecho hombre"105.

\section{0.- APLICACIONES DE ESTA DOCTRINA A LA CONVIVENCIA.}

Tal era la doctrina general que regulaba la vida. Las aplicaciones no se hacían esperar, algunas de ellas terribles. La coherencia de estos hombres es admirable. Llevaban hasta sus últimas consecuencias las creencias sobre las que se sustentaban, si bien algunas de ellas deberían haberles llevado a cuestionar los principios que tenían por evidentes. Pero para ellos ceder a lo humano, al razonamiento meramente humano, hubiera sido pecado. Ser buen religioso era encajarse, ahormarse en estos principios. Para poner un poco de orden en la materia, dada la abundancia de textos de que dispongo, haré dos apartados. En el primero estudiaré las relaciones del religioso fuera del monasterio; en el segundo, sus relaciones dentro de él.

\section{A) Relaciones fuera del monasterio}

\section{a) Relaciones familiares}

¿Se puede amar a la familia? Se la puede amar con amor espiritual, "como a uno mismo", como se debe amar a todo hombre. El amor humano

100. Arte de amar a Dios y al prójimo, 8, I, 236.

101. Cf. San AGUSTÍN, Regla, VI, 43.

102. Cf. Id.: Ib., V, 31.

103. Cf. Id.:Ib., I, 3; Id., Comentarios a los salmos., 132, 1-13. Instrucción de religiosos, Sevilla 1551, 5, 61-62.

104. San AGUSTÍN, Regla, I, 9.

105. Regla de Nuestro Padre San Agustín, Madrid, Antonio Sánchez 1781, 1, 17. En adelante, la citaré como Regla, y citaré capítulo y número por esta edición. 
hay que extirparlo, sobre todo el de los familiares. "La primera [cautela] es que acerca de todas las personas tengas igualdad de amor e igualdad de olvido, ahora sean deudos, ahora no, quitando el corazón destos tanto como de esotros, y aun en alguna manera más de parientes, por el temor de que la carne y la sangre no se avive con el amor natural que entre los deudos siempre vive, el cual conviene mortificar para la perfeción espiritual. Tenlos todos como por extraños, y desta manera cumples mejor con ellos que poniendo la afición que debes a Dios en ellos"106 . La doctrina valía tanto para los religiosos como para los seglares, pues el modelo de santidad era único ${ }^{107}$.

106. San JUAN DE LA CRUZ, Cautelas, $n^{\circ}$ 5. Sto. TOMÁS DE AQUINO defendió, de acuerdo con el axioma de que "la gracia perfecciona la naturaleza, no la destruye", que Dios no es el único objeto del amor en el orden de la caridad, sino que lo son también los hombres, y que la caridad no es la única razón para amar al hombre; también lo son los lazos de carne y sangre y otros, todos ellos meramente humanos, como los que hay entre esposos, padres e hijos, hermanos, amigos... Pero no se atendieron sus razonamientos, y se siguió condenando todo afecto humano. Cf. S. TH., I-II, qu. 26-28; II-II, qu. 23-26; James EVOY, Amitié, attirance et amour chez S. Thomas d'Aquin, en Revue Philosophique de Louvain 91 (1993) 383-408; Juan Martín VELASCO, Experiencia mística y experiencia del hombre y del mundo, en Iglesia Viva 161 (1992) 451-458.

107. Tal doctrina permaneció inmutable hasta bien entrado este siglo, y aún se practica en determinadas Congregaciones Religiosas, no solo en las sectas. En 1933 se publicó la traducción española de las Vitasfratrum del agustino Jordán de Sajonia (h. 1290 - h. 1370) con el título de Vidas de los hermanos, traducción del P. Dámaso Martínez Vélez, con anotaciones del P. Pedro Martínez Vélez. El c. X del libro I, Vol. I, pp. 74-78, trata de que no se debe dejar la soledad por atender las necesidades corporales del prójimo. Confirma su doctrina con algunos ejemplos de los Padres del Yermo y de un hermano agustino. El religioso tiene que vivir ajeno a los asuntos de este mundo, desasido de su familia, absorto en Dios. En la nota 1 de la página 78, dice el P. Pedro Martínez Vélez: "la relación del religioso con el mundo exterior, incluso con su familia, debe ser la menor posible, como no sea por legítimos fines espirituales. Asímismo debe olvidar el camino de su pueblo, como no sea por esos fines. Lo exigen la flaca naturaleza humana, la índole de la vida monástica y la doctrina revelada". Y cita en corroboración de lo dicho Sal 45 (44), 11-12 y Lc 14, 26.

Bien conocía esta doctrina Gabriel Miró. Estas son las reflexiones del hermano portero de un colegio jesuítico de alumnos seglares : "A esa costosa cumbre [de la santidad] únicamente puede subirse por los caminos de la humildad, de la renunciación de todos los afectos [...]. Y cada vez que repicaba el esquilón de la portería, el hermano botaba de pesadumbre. ¡No podían vivir sin quererse, sin besarse, sin tocarse! ¡Oh qué engaños y peligros tenían los alumnos en sus familias; y singularmente en la madre, en la madre y en las hermanas! [...]. Las de Oleza, que gozando de locutorio todos los jueves y domingos, apartaban a los colegiales del recogimiento del Viernes Santo" (El obispo leproso, c. IV, en Obras escogidas, Aguilar, Madrid 1967, 4a , 908). Una madre va a visitar a su hijo la tarde del Viernes Santo. Madre e hijo se besan. "Y el hermano portero los separó diciendo: ¡en esta tarde, Nuestra Señora no pudo besar a su Hijo sino después de muerto" (Íb., íb., 910). "El hermano abría despacito, queriendo retardar el instante de abrirles las puertas de la perdición.- Acuérdense del $<$ Bendita sea tu pureza $>$.- No se apure hermano.- Y el santo los veía alejarse con un celoso furor: Los grandes peligros de las vacaciones andaban dentro de las familias: vestidos, olores, risas. Para todas era menester un internado perpetuo" (Íb., c. V, íb., 947). Si esta era la doctrina respecto a los seglares, no es extraño que no se permitiera a los religiosos volver a casa 
Las crónicas religiosas de antaño no dejan lugar a dudas. El religioso tenía que romper con su familia. Y es precisamente a los más huraños a quienes los cronistas proponen como modelos. Dios llama a los religiosos, como llamó a Abrahán, a salir de su lugar de origen; a dejar a sus padres y parientes para amarle a él, solo a él, según textos ya citados.

Quien es amigo de Dios, quien está en gracia, se ama a sí mismo. ¿En qué sentido? "El amor caritativo con que se aman los amigos de Dios es un aborrecimiento santo que tienen con su cuerpo y ámanle para Dios y por tanto le castigan. y le sujetan al espíritu, como san Pablo afirma de sí mismo (1 Cor 9,27)"108. Amar el cuerpo es castigarlo, negarle todo placer, amarlo para Dios. Amarse a sí mismo es despreciarse como hombre, humillarse, renunciar a lo humano, amarse solamente en Dios y para Dios ${ }^{109}$. Así hay que amar al prójimo, "como a ti mismo" (Mt 22,39), para Dios; y si los que tienen autoridad tienen que castigarle, le castigan, no excluidos los azotes. "Ahora está claro cómo se ha de amar al prójimo, que es para el fin que yo me amo o debo amarme a mí. Este ha de ser el compás con que se han de compasear todas las amistades y la regla con que se ha de medir todo afecto, aunque sea de padre a hijo y de hijo a padre, porque, como dice san Gregorio, si no sube de amor natural el de los parientes no merece premio eterno. ¿Oh cuánto se había de examinar este punto de amor entre cristianos![...]. ¡Que gente tan cristiana, tan sabia y enseñada con avisos del cielo, amen tan groseramente y tan por respetos de sangre! Lástima es que por no saber, o por mejor decir, no querer usar de este arte divino en amar a sus hijos, padres y hermanos, refiriendo aquel amor a Dios y amándolos por él, se queden sin muchos grados de gloria" 110 .

Los esposos tienen que amarse con amor espiritual, no carnal; con amor de caridad, no con amor natural. Amar lo que en ellos hay de común con los demás hombres: el ser humano, la naturaleza humana; no lo propio y particular de cada uno de ellos. Amarse como hijos de Dios, en Dios y para Dios. Amarse con afecto humano, complacerse humanamente, desearse es concupiscencia; es amarse como infieles, tizones para el infierno, que no saben amarse. Lo dijo san Agustín: el ser esposa o esposo se acaba con la muerte, es

de sus padres, ni aun en caso de la muerte de estos. El religioso, se decía, tiene que retorcerse el corazón. Para eso se ofreció a Dios en holocausto.

108. Arte de amar a Dios y al prójimo, 13, I, 246.

109. "El rayo de la cólera verbal de Tertuliano se encendía en la lengua del indomable justo [el P. Bellod, cura parroco en Oleza] pensando en las indignidades del matrimonio y viendo que sus criaturas no se amaban a sí mismas hasta el propósito de la continencia" (Gabriel MIRÓ, Nuestro Padre san Daniel, c. II, en Obras escogidas, edic. cit., 576).

110. Arte de amar a Dios y al prójimo, Ib., Ib. 
algo terreno y pereccedero, no así el ser hijos de Dios. Hay que amar lo eterno y aborrecer lo temporal.

"El buen cristiano ama en su mujer la criatura de Dios y odia la unión y cópula corruptible y mortal. Es decir, ama en ella el ser hombre y aborrece el ser mujer. Así como ama a su enemigo, no por ser enemigo, sino por ser hombre, hasta el punto de desear que le acontezca lo que desea para sí, es decir, que se corrija y llegue, renovado, al reino de Dios. Esto mismo ha de entenderse del padre, la madre, y los demás vínculos de sangre, para que en ellos aborrezcamos lo que al género humano le cabe en suerte al nacer y morir, y amemos, en cambio, lo que puede ser llevado a aquel reino en nuestra compañía"111.

"Habéis de amar a vuestra mujer como Cristo amó a su Iglesia, con amor casto y espiritual. Así lo dijo el Apóstol hablando con todos los casados. Muy otro ha de ser el matrimonio de los cristianos, gente que conoce y ama a Dios, que el de los bárbaros e infieles, que son ignorantes y para tizones del infierno. Y así el amor que se han de tener ha de ser en Cristo y por Cristo, para que por esta vía merezcan el cielo y descanso perpetuo. Cosa baja sería tenerse amor por otros respectos groseros y viles que los casados infieles tienen. Por tanto, ha de ser el fundamento para que no desdiga este edificio el amor de Dios"112. Matrimonio perfecto fue el de la Virgen y san José113.

Nada más natural que los hijos amen a los padres. ¡Cuidado con lo natural! Porque ahí se esconde el pecado. Latet anguis in herba, decía un proverbio latino. Recordándolo, escribió fray Luis de León: "retira el pie, que asconde / sierpe mortal el prado, aunque florido"114. Cuidado con lo natural, de manera muy especial con esta relación de carne y sangre, que está especialmente envenenada; como que por ella se transmite el pecado original. En los padres hay que amar lo espiritual y eterno, no lo carnal y efímero, como acabamos de leer en san Agustín.

Todos recordamos la escena. Agustín, recién convertido, vuelve a África con los suyos. Se detienen en el puerto de Ostia. Mónica, su madre, muere. Como llorón que es, Agustín quisiera llorar a raudales, dar suelta a su dolor; pero se reprime hasta el punto de que los demás le juzgan "sin sentimiento de dolor". Un filósofo no debe llorar. Meditación de la muerte es la filosofía. Ante la muerte, debe mantenerse impávido. Abstine et sustine, renuncia y

111. San AGUSTÍN, El sermón de la montaña, I, 15, 41; cf. José VEGA, La vocación agustiniana. El proyecto filosófico-monástico-sacerdotal de san Agustín, edic. cit., 67-77; Id., Sobre el "amor mutuo" de los criatianos, loc. cit., 108-111.

112. Epistolario cristiano, 7, I, 140.

113. Cf., Ib., 131; Catecismo cristiano, 21, I, 446.

114. Poesias, XIII, 11, vv. 11-12, edic cit, 1454. 
aguanta. Al fin, a solas, logró dar salida a su aflicción y se serenó. Pero ¿qué dirán sus lectores? ¿Qué dirán, sobre todo, los monjes'. Un monje no llora por la pérdida de las ataduras humanas. Se ha liberado de ellas, sobre todo de las de carne y sangre. Pertenece a Dios, a nadie más. Y Agustín se arrepiente, y pide perdón por haber llorado a su madre muerta, aunque solo haya sido "escasamente una hora" 115.

Su relato fue, sin duda, ejemplar para sus lectores, pero a nosotros nos resulta extraño, porque los razonamientos que subyacen nos parecen deleznables, filosofía de saldo. Se los expone en una carta al novicio Leto. Este había ido a su casa por asuntos familiares y, retenido por su madre, no veía modo de volver al monasterio. Es tu madre ahora; no lo será tras la muerte, le dice Agustín. Es tu madre, tuya; no mía ni de ningún otro. En cambio, como hija de Dios y hermana en Cristo, es tuya, mía y de otros muchos; y lo será siempre, aquí y en el reino futuro. Esto es común y público; aquello, privado y propio. Ama lo común, que es eterno, y aborrece lo propio, que es transitorio. Esto propio debe servirte "para hablarle con más familiaridad y aconsejarle abiertamente que mate ese amor particular con que te ama, no sea que prefiera el haberte engendrado en su vientre al haber sido engendrada contigo en el vientre de la Iglesia"116.

En el Antiguo Testamento, dice el beato, se mandó a los nazareos, que eran los religiosos de entonces, que no llorasen la muerte de sus padres ( $\mathrm{Nm}$ $6,6-7)$. Se llora la pérdida de lo que se ama, razona él. Si se prohibe llorar la muerte de los padres, está claro que se prohibe amarlos. Es decir, "que los religiosos hemos de estar tan muertos al mundo, tan desviados de todo, que amando de todo corazón a Dios, nada de esta vida nos dé tristeza, cuando nos faltare, aunque sea el amor tan natural como lo es del hijo al padre [...]. El dolor nace del amor que se tiene a lo que perdemos [...]. Luego el que no quiere tener tristeza y dolor perdiendo lo que es temporal tenga un aviso, y es que no lo ame [...]. No le amen ni se traben de él aficionándose a cosa alguna, porque lo que no se posee con amor sin dolor alguno se pierde. $Y$ aunque a todos y para todos los cristianos nazareos, consagrados a Dios en el santo bautismo, se da esta ley, así espìritualmente entendida; mas principalmente habla con nosotros, que nos adelantamos y señalamos entre el pueblo cristiano, para que, dejado el mundo, nos empleemos en servir a Jesucristo, Rey y Señor nuestro [...]. Mandaba Dios que los nazareos no bebiesen vino, queriendo el Señor que nos guardemos del amor apasionado de las criaturas, que

115. Confesiones, IX, 12, 29-33. Cf. José VEGA, La vocación agustiniana..., edic. cit., 148-150.

116. Cartas, 243, 4: cf. José VEGA, op. cit., 216-218; Id., Acción y contemplación, en Estudio Agustiniano 31 (1996) 314-316. 
embriaga y mata el alma [...]. Y, finalmente, no quiere que lloremos pérdida alguna de lo temporal, aunque sea perder el padre o la madre, sino quiere Dios que, como gente muerta al mundo, estemos tan conformes a la voluntad de Dios en todo, que nos sea dulce lo que él quiere hacer de nosotros y de nuestras cosas. Esta es perfección muy alta y no es mucho que un religioso trabaje de subir a ella"117. "Habéis de amar a los enemigos y amigos. A los unos por Dios y a los otros en Dios. Porque ni a vuestro propio padre habéis de amar sino en Dios"118.

El cristiano, mucho más el religioso, no puede amar a sus padres por ser sus padres. Eso sería amor carnal. Tiene que amarlos para el cielo, como a hijos de Dios, como a sí mismo, tal como mandó el Señor. Pero hay un mandamiento que manda honrar a los padres. Hay que atenderlos porque Dios lo manda; no por razones de sangre, sino por amor de Dios, amando a Dios en ellos. El beato censura a los religiosos que apostatan por ayudar a sus parientes 119 . Concede, sin embargo, que "el hijo religioso profeso es obligado a pedir licencia a su prelado y ir a remediar la necesidad extrema de sus padres, según los doctores determinan"120. ${ }_{\text {iEn }}$ extrema necesidad y con licencia del Superior! Y esto no por afecto filial, sino porque lo manda Dios.

Tan desafecto debe estar el religioso a sus padres, dándoles ya por muertos, que "no habéis de hablar ni pensar en linaje, que ya todo murió"121.A la doctrina tradicional sobre el amor a los padres se añadía en el siglo XVI el temor de que en esas conversaciones se colase en el monasterio el problema de la honra, y, en España, el de las castas de cristianos viejos y nuevos, de judíos y moriscos, tan agudizado entonces. Son muchos los textos en que santa Teresa, de ascendientes judíos, previene a las monjas sobre puntos de honra, y cómo han de huir de ellos en sus conversaciones, como muy inteligentemente señaló Américo Castro ${ }^{122}$. Las monjas del monasterio de la Encarnación de Madrid agustinas recoletas tenían prohibido hablar de sus padres y de cosas mundanas ${ }^{123}$.

117. Epistolario cristiano, 5, I, 92-93.

118. Regla de vida cristiana, documento, 5, II, 386.

119. Epistolario cristiano, 5, I, 103-104.

120. Catecismo cristiano, I, 436.

121. Desposorio espiritual, introducción, II, 437

122. Cf. Teresa la santa y otros ensayos, Alfaguara, Madrid-Barcelona 1972, 20-23 y 8182. Hoy está ya documentada su ascendencia judía.

123. Cf. María Leticia SÁNCHEZ HERNÁNDEZ, El monasterio de la Encarnación de Madrid. Un modelo de vida religiosa en el siglo XVII, Edic. Escurialenses, Real Monasterio de El Escorial 1986, 164. 
Lutero acusaba a los frailes, ¿sin razón?, de no amar a sus padres y de no cumplir el cuarto mandamiento de la ley de Dios ${ }^{124}$. San Vicente de Paúl, tan desprendido de sí mismo, tan entregado en cuerpo y alma a los necesitados, no amaba a sus padres. A alguno quizá le extrañe en un alma tan de Dios; pero precisamente por esto no los amaba. Fue el amor de Dios, tal como lo entendía la tradición, lo que le desinfectó de las afecciones de carne y sangre con sus padres. "Tanto rogué a Dios, que finalmente sintió piedad de mí; él me arrebató los sentimientos amorosos hacia mis padres; y aunque ellos hayan tenido que vivir de limosna y aún sigan viviendo de ella, me ha concedido la gracia de abandonarlos a su providencia y saberles más felices que si estuvieran acomodados"125. ¡Increíble, pero cierto! No hizo más que ser consecuente con la doctrina. San Vicente de Paúl amaba a sus padres en Dios, por Dios y para Dios; es decir, con caridad o amor cristiano. Por esto no los amaba con afecto filial, que es afecto de carne y sangre, pecado. Hay que olvidarse de todos, sobre todo de los padres, nos ha dicho san Juan de la Cruz.

$\mathrm{El}$ amor a los hijos se regía por los mismos principios. El piadoso Pascal, jansenista, reprochaba a su hermana que acariciase a sus hijosi26. A santa Juana Francisca de Chantal su hijo de catorce años se le tendió en la puerta para impedirle que partiera a fundar la Visitación. Ella, llorando, vaciló; pero acabó por marchar allí "donde Dios la llamaba"127. Era lo que en casos semejantes había aconsejado san Jerónimo: "pisa al padre y sigue adelante", se lee en su carta a Heliodoro, como recuerda santa Teresa128. En su famosa Historia del sentimiento religioso en Francia, $\mathrm{H}$. Bremond ha contado este caso y el de María de la Encarnación y su hijo de doce años. "La lectura de este capítulo es casi insoportable"129. Madre e hijo sentían que se les arrancaba el alma, "pero mi amor por Dios era superior a todo esto", dice la madre, que ingresó en las ursulinas de Tours, y más tarde partió para Canadá. Su hijo intentó varias veces penetrar en el convento con otros chicos del pueblo para rescatarla. Más tarde se hizo benedictino y fue un monje ejemplar. Ni la madre ni

124. Cf. Jean DELUMEAU, La Reforma (Nueva Clío 30), Edit. Labor, Barcelona 1973, $2^{\mathrm{a}}, 36$.

125. Cit. por Jean DELUMEAU, El catolicismo de Lutero a Voltaire (Nueva Clío 30 bis), Edit. Labor, Barcelona 1973, 55.

126. Cf. José JIMENEZ LOZANO, La ronquera de fray Luis y otras inquisiones (Col. Áncora y Delfín 426), Ediciones Destino, Barcelona 1973, 34 y 231-235.

127. Jean DELUMEAU, El catolicismo de Lutero a Voltaire, edic. cit., 55. El episodio lo recuerda una religiosa en Gabriel MIRÓ: "este hijo se tendió en el umbral de la casa para que la madre retrocediera. La santa le miró y pasó por encima del hijo, para bien de nosotras, sus hijas verdaderas" (El obispo leproso, c. IV, en Obras escogidas, edic, cit, 880).

128. Santa TERESA DE JESÚS, Vida 3, 7 y 4, 1.

129. Jean DELUMEAU, $i b$., $i b$. 
el hijo llegaron a convencerse de que semejante arrasamiento del hombre fuera voluntad de Dios.

A los hagiógrafos de la época estos y otros muchos casos semejantes les parecían ejemplares. Algunos de sus protagonistas han sido canonizados. Hoy serían llevados a un juzgado de guardia. Ante casos así, uno no puede dejar de recordar el dicho de Jesucristo contra los fariseos: "ya no le dejáis hacer nada por el padre o la madre, invalidando el mandamiento de Dios con esa tradición que os habéis trasmitido. Y de estas hacéis muchas" (Mc 7, 12-13)130.

El beato Orozco recuerda el caso del filósofo Anáxagoras, que, al anunciarle que un hijo suyo al que quería mucho había muerto, respondió: "no me decís cosa alguna nueva, porque yo bien sabía que engendré hijo mortal [...]. Afrenta para los cristianos que hacen extremos y no acaban de llorar sus difuntos, como si no fueran mortales"131. David hizo gran penitencia y suplicó a Dios por su hijo enfermo. Cuando supo que había muerto "cesó de llorar y pidió de comer", diciendo a sus criados: "ya no hay para qué llorar, pues yo tengo de ir adonde él va y él no ha de volver a esta vida mortal"132.

Cuidado especial deben tener los padres con sus hijas, "que son vasos más quebradizos y tienen mayor peligro [...], apartándolas de toda ocasión mala y encerrándolas para que con nadie traten ni oigan cosas que no sean de Dios"133. Aparece aquí el tema de la guarda de la mujer, animal de mucho cuidado, nacido para la sujeción. Sabido es que santo Tomás de Aquino, con Aristóteles, dos autoridades indiscutbles, la llamó mas occasionatus, un macho frustrado. Un ser que venía para varón; pero, por anomalías de la naturaleza, se quedó en el camino, con una razón defectuosa, apenas razón, y un alma demediada. "La mujer de su natural [es] flaca y deleznable más que ningún otro animal"134. "Salomón dice que su padre no la mire con ojos amorosos, esto porque no se engrían y se ensoberbezcan, sino que teman y se humillen, no haciendo caso de ellas" 135 .

Con la misma caridad hay que amar a los hermanos, aunque menos que a los padres 136; pero también "con amor fuerte por el cercano parentesco que con ellos tenemos"137 y "refiriendo aquel amor a Dios y amándolos por él"138

130. Cf. José VEGA, La vocación agustiniana...., edic. cit., 547-548.

131. Epistolario cristiano, 12, I, 210.

132. Ib., Ib. ; cf. Victoria de la muerte, 31, I, 551-552.

133. Epistolario cristiano, 7, I, 141. 245.

134. Fray luis de LEÓN, La perfecta casada, en Obras completas castellanas, edic. cit., I,

135. $I b ., i b .135$.

136. Cf. Monte de contemplación, 6, II, 136.

137. Desposorio espiritual, 5, II, 449.

138. Arte de amar a Dios y al prójimo, 13, I, 246. 
La casuística es aquí tan pintoresca que no me resisto a dar este texto: "entre los prójimos, unos se han de amar más que otros. Más se han de amar los padres que los hijos y más al padre que a la madre por razón de ser más principal principio. Más se han de amar los criados de una casa que los extraños"139. En la generación, el padre es la virtud generativa, que configura, bajo la influencia de la causa primera, el gurruño de sangre que encuentra en la madre, según entonces se creía. El principio activo es superior al pasivo. Merece ser más amado. ¡Cosas del discurrir en virtud de los principios recibidos! ¡Tan espirituales y tratan al hombre como pura zoología!

\section{b) Visitas y salidas del monasterio}

A veces, el religioso tiene que dejar su celda, bien porque le visitan, bien porque tiene que salir del monasterio. Son dos ocasiones de demostrar lo que ha aprendido en el recogimiento, y de cuán a su pesar lo abandona. Momentos de convivencia con los seglares, pero también con los religiosos, porque siempre estará acompañado por alguno de ellos para que mutuamente se vigilen. Momentos que el religioso no escoge por su voluntad, sino que los acepta por obediencia.

"Jamás salgáis a las redes, pidiendo licencia, sino mandada por la obediencia, porque no se enrede vuestra alma de algún pecado, aunque pequeño, yendo por vuestra voluntad. Así como el religioso jamás debría salir sino siendo mandado, porque al fin otra cosa es la plaza y muy otra la celda; una cosa las calles y otra el monasterio, pues en las plazas llora Jeremías que los religiosos nazarenos no eran conocidos. Bien así la religiosa en ninguna manera había de ir al locutorio sino compelida de su prelada, porque de grandes peligros guarda la obediencia, en los cuales suele poner la propia voluntad"140. "Las que más siguen las redes y el locutorio más enredan sus almas para no orar con libertad en el coro. Jamás vayáis a locutorio por vuestra voluntad, sino mandada por la obediencia. Hablad allí de Dios y con brevedad os volved a vuestro recogimiento, que en verdad que saldréis más consolada de una oración breve y plática que tengáis con vuestro Esposo, Cristo, que si todo vuestro linaje os viniese a visitar al monasterio"141.

Consideración especial merecen los días en que se ha comulgado. "En tan santo día, no es razón que haya libranza para el locutorio, sino que la esposa

139. Ib., Ib., 247.

140. Desposorio Espiritual, 3, II, 445-446.

141. Íb., 4, II, 447-448. 
devota de Cristo se retraiga a solas con su divino Esposo, diciendo con la esposa lo que dice en los Cánticos: mi amado Esposo para mí y yo para él (Cant 2,16)"142. También los seglares deben andar con cautela en esos días y abstenerse de "hacer visitaciones, teniendo aviso que por la boca que entró la vida no salga palabra digna de muerte"143.

"Estar en continua clausura, circuncidar todo lo superfluo [...], la soltura de los sentidos, la libertad de las salidas del monasterio, no siendo mandado"144. "El monasterio es un sepulcro de por vida. Nadie le ha de sacar de él si es muerto y sepultado con Cristo, sino la obediencia del prelado" 145 . "Excusar las salidas del monasterio (si no mandare la obediencia otra cosa)"146. "No saldrá del monasterio sino cuando lo manda el prelado; y, acabada la obediencia, con alegría se volverá a su celda el que contra su voluntad salió fuera, y, dando gracias a Dios, dirá con el santo Job: en mi nidillo me moriré"147. "Mirad que vuestro monasterio es nido, el cual vuestra alma eligíó, como tórtola casta, para en soledad y retraimiento mejor reposar y con santos ejercicios y fervientes deseos más altamente volar para Dios. De aquí, como de nido encerrada, habéis de llamar con gemido [...]. No queráis por ocasión alguna, aunque sea extrema enfermedad, volver ni por un día al siglo [...]. ¿Qué no temerá la persona religiosa la salida de su monasterio, al cual nunca vuelve el alma tan quieta y pacífica como primero salió? San Bernardo dice que como es imposible los peces vivir mucho tiempo fuera del agua, así es dificultoso el religioso conservarse sin pecado mucho tiempo fuera del monasterio [...]. A morir venimos a la religión; no nos debe espantar la clausura. Por eso se llama nido el monasterio, porque en él todo ha de ser pobre y penoso, usando de pobre celda, pobre vestido y pobres manjares"148.

$\mathrm{El}$ arrullo de la tórtola se oye en el Cantar de los Cantares $(2,13)$ como anuncio de la primavera, tiempo de amor. En la tradición literaria, a la tórtola se le unieron otros rasgos; castidad, retraimiento y dolor. Cuando enviuda, en ninguna parte halla consuelo; no posa en ramo verde y, antes de beber, enturbia el agua clara, se lee en el romance de Fonte frida. El epíteto que la acompañaba era el que le aplica Orozco: casta. Casta, solitaria, desgarrándose en gemidos de fervientes deseos: así quiere el beato a la religiosa. Casta con corazón indiviso, con amor perfecto, "como lo es el que dos tórtolas,

142. Epístola para doña Isabel de Orellana y Orozco, III, 458.

143. Regla de vida cristiana, documento 5, II, 394.

144. Desposorio espiritual, epístola a un religioso, II, 462.

145. Tratado del sacramento de la penitencia, 16, I, 352-353.

146. Epistolaio cristiano, 5, I, 105.

147. Tratado de la suavidad de Dios, 34, II, 555.

148. Memorial del amor santo, 14, II, 247-248. 
macho y hembra, se tienen entre sí, que, como se escribe, es tan grande y fiel que, muerta la una, la otra se condena a perpetua viudez", comenta fray Luis de León 149

Se reciben visitas o se sale del monasterio tan solo por mandato del superior, y siempre con la compañía de aquel a quien el superior mandare, que hace entonces sus veces. Sobre las visitas no he encontrado textos en los que se mande esta presencia de otro religioso, pero la práctica, al menos para las religiosas, era la misma que en las salidas del monasterio.

"Gran cosa es la compañía y mucho edifica a los cristianos ver al religioso acompañado de otro religioso. No es pequeña estima llevar consigo un ayo, testigo de sus palabras y obras; y aun no es pequeña la prudencia del prelado en saber dar un compañero a cada religioso cuando sale del monasterio. Pues por entonces aquel es su prelado, que le ha de mirar y guardar y volver al monasterio donde le sacó, llevándole a su cargo. Aquí es menester gran espíritu y gran miramiento y del cuido en esto habrá estrecha cuenta para con Dios"150.

El religioso no puede andar solo por el mundo. Tiene que hacerlo compañado. Necesita siempre un superior, un ayo que le tenga a su cargo: es un niño. El superior del monasterio, y este ocasional que acompaña al religioso, tendrá que dar "estrecha cuenta" a Dios de su oficio, de los niños a él confiados. El concilio Vaticano II pontificó muy solemnemente, como lo requería la ocasión: "la obediencia religiosa, no solamente no menoscaba la dignidad de la persona humana, sino que, con la amplia libertad de los hijos de Dios, la lleva a su madurez"151. ¿Dónde queda la persona, su dignidad y madurez, en los términos en que hoy hablamos de estos temas, con la obediencia tradicional? ¿Cómo se puede perfeccionar aquello a lo que se renuncia, la libertad, porque es, así se decía, la fuente de todo mal? ¿Cómo tendrá que ser la obediencia para que no destruya, sino que impulse, el desarrollo personal?¿Podrán

149. Exposición del Cantar de los cantares, 1, 10, en Obras completas castellanas, edic. cit. Cf. Íb., 2, 12-13; De los nombres de Cristo, 1, Pastor, 448; In Cant. cant. triplex explanatio, texto bilingúe de José María Becerra Hiraldo, Ediciones Escurialenses, Real Monasterio de El Escorial 1992, 1, 2, 60 y 2, 2, 151-152. (La traducción lleva por título Cantar de los cantares). Sobre la tórtola en la tradición literaria, cf. Eugenio ASENSIO, Fonte frida o encuentro del romance con la canción de mayo, en Poesía y realidad en el cancionero peninsular de la Edad Media (Biblioteca Románica Hispánica II, Estudios y Ensayos 34), Edit. Gredos, Madrid 1957, 246-249; Marcel BATAILLON, La tortolica de Fonte frida y del Cántico espiritual, en Varia lección de clásicos españoles (Biblioteca Románica Hispánica II. Estudios y Ensayos 34), Edit. Gredos, Madrid 1964, 144-166; Miguel QUEROL GAVALDÁ, I. Madrigales españoles del siglo XVI. II. Cancionero de la casanatense, transcripción y estudio por-, CSIC,. Instituto Español de Musicología. Barcelona 1981, 11, 21 y 99-103.

150. Regla, 3, 4.

151. Perfectae Caritatis, 14. 
alguna vez atarse estos dos cabos? Aquí, como en otras ocasiones, el Concilio, resultado de dos corrientes encontradas, ató moscas por el rabo con una facilidad que asombra.

Según los maestros del pasado, niño es el religioso de por vida, un irresponsable, y de por vida necesita un ayo. Niño y ayo, en sus salidas del monasterio, deben vigilarse mutuamente, espiarse cautelosamente y dar cuenta al superior de lo observado. Su consigna es la de la pareja de la Guardia Civil: "paso corto, vista larga, mala intención y desconfiar siempre del compañero". Pero todo esto, ya se sabe, se nos dice envuelto en celofán piadoso.

"También ha de temer el que va con otro religioso, si no mirare y estuviere en su presencia, no le diga Dios como a Caín: ¿dónde está tu hermano Abel? (Gn 4,9). ¿Cómo le has dejado perder apartándote de él? Cierto no podrá decir con verdad: ¿Señor, por ventura soy yo guarda de mi hermano? Y si lo dijere será para su condenación, como fue al traidor de Caín. No sin gran misterio mandó Dios (Éx 25, 20) que aquellos querubines que estaban sobre el arca fuesen de oro y dos y que se mirasen el uno al otro. Dos querubines son los dos religiosos que salen del monasterio; y de oro, si se aman con el amor espiritual que Dios manda. Míranse como querubines cuando cada uno guarda y mira las faltas del otro y se las corrige con caridad. Mirarse uno a otro es ir juntos y estar juntos, no perdiéndose de vista el uno al otro, como aquí manda N. P."152. "Cada un religioso ha de mirar por su hermano y no descuidarse en guardar el alma que el prelado le dio a su cargo"153. Acompañado salía el beato siempre que iba a predicar, a visitar enfermos o a palacio ${ }^{154}$.

Tanto en las visitas que se reciben en el monasterio como en las salidas que se hacen, el modelo es la Virgen María en su visita a santa Isabel, misterio al que el beato dedicó uno de los dos monasterios de religiosas por él fundados en Madrid, los dos de espíritu recoleto. No debió de ser mera coincidencia que la recolección agustiniana, que más tarde dio origen a los agustinos recoletos, se decretase en el Capítulo Provincial de 1588, en el que fue elegido provincial el P. Pedro de Rojas, cabeza del bando de la reforma y confesor del beato Orozco, y se comenzase en el convento fundado por este en Talavera de la Reina. Su hábito era, por pobreza, como el adoptado después por los recoletos, dice un recoleto en el proceso de beatificación ${ }^{155}$.

152. Regla, 3, 5 .

153. Íb., íb., 10 .

154 Cf. Carlos ALONSO, Agustinos en el proceso de beatificación del beato Alonso de Orozco, en Estudio Agustiniano 26 (1991) 362, 366 y 368.

155. Cf. id., íb., 380. 
Aprendamos de la visita de la Virgen cómo tenemos que hablar en las visitas y salidas del monasaterio, y aprendan los seglares cómo tienen que hablar en sus visitas. "A lo menos yo osaré decir una cosa, y saldría por fiador de ella, que nuestra Señora no hizo la cortesía vana que aquí usáis bien inventada de la vanidad del mundo, beso manos, beso pies de vuestra merced. ¡Oh tosquedad grande! ¡oh grosería peor que de aldea! ¿Qué decís, cristianos, que habéis de tener lenguaje del cielo y hablar palabras del espíritu? ¿Cómo no aprendéis a hablar? $\mathrm{Y}$ es lo peor que como centellas saltan ya estas vanas cortesías entre eclesiásticos y entre religiosos. Cristiano, yo no sé qué te diga, pues hablas al talle del mundo vano, sino lo que fue dicho a san Pedro en casa de Caifás. Tu manera de hablar te declara y manifiesta quién eres. Y como dice nuestro Salvador, de la abundancia de tu corazón salen estas palabras a la boca. [Si de toda palabra ociosa habrá que dar cuenta], ¿por qué echáis palabras al aire? [Solo al Papa se le ha de decir "beso los pies de vuestra santidad", y solo a los sacerdotes "beso las manos", pues están consagradas]. Nuestra Señora no hizo la cortesía tonta y tosca que los mundanos tanto usan, no entendiendo su simpleza y falta de saber"156.

Asoma aquí el perfil montaraz y el ademán adusto y desaliñado del asceta, el onagro que todo monje llevaba dentro, también los que trataban en la corte de los reyes.

Cuidado especial debe tener el religioso siempre que tenga que tratar con mujeres. Lo veremos en el apartado dedicado a la modestia.

\section{c). Huir de las relaciones humanas}

En resumen, en cualquier relación con los hombres el principio es siempre el mismo: hay que evitarla; hay que estar con Dios, solo con él y solo a él hay que amarle por él mismo. Desde él se va por necesidad, solo por necesidad, al prójimo, al que hay que amar en Dios, por Dios y para Dios. Qué estragos llegó a causar esta doctrina ya los hemos visto. Se podrían multiplicar los ejemplos. Podemos imaginarnos la tortura a que estaban sometidas las almas piadosas en el momento de la confesión o en el examen de conciencia diario; la sutileza y finura con que tenían que someter a discusión sus actos ${ }^{157}$.

156. Tratado de las siete palabras que María santísima habló, 3, III, 217.

157. Cf. San AGUSÍN, Confesiones, X, 28, 39 -41, 66, en que se examina con rigor sobre los residuos de la triple concupiscencia que aún quedaban en él. Sólo Dios es dueño del alma por derecho, y sólo él debe serlo de hecho. Aterrado "por sus pecados y miseria", Agustín proyectó "huir a la soledad", lejos de los hombres, y entregarse a Dios en la contemplación como un anacoreta. Pero Dios se lo prohibió recordándole que "Cristo murió por todos" (2 
No es extraño que abundasen tanto los escrupulosos. El beato lo fue durante muchos años. Todo ello generó una copiosa producción de manuales y tratados sobre el particular, de casos y confesionarios. El examen sobre la caridad, así entendida, lo trató el beato en varias de sus obras y a él le dedicó la parte más extensa del examen que escribió para la confesión al final del Tratado del sacramento de la penitencia.

\section{B) Relaciones dentro del monasterio}

\section{a) Soledad, no convivencia}

Ahora nos explicamos por qué estos hombres, que todo lo regulaban, no dan normas sobre la convivencia en la comunidad religiosa. O mejor, las dan; pero es para prohibir las relaciones entre los religiosos. Para ellos lo valioso era la soledad en Dios; esa era la única realidad y a ella había que sacrificarlo todo. El trato con los demás, incluidos los religiosos, distraía, apartaba de Dios, era un estorbo. Lo que privaba era el individualisno religioso. "Oh buen Jesús, a vos quiero, a vos busco y a vos desea amar mi alma [...]. Nada es bastante a mis deseos sino vos, descanso y paz de mi corazón, a quien todo le es penoso y toda criatura le es verdugo atormentador. En vos está mi descanso; vos solo sois mi consuelo"158.

Cada uno, dicen estos maestros del espíritu, se perfecciona en su soledad, él solo con Dios solo. Cada uno en su celda y Dios en la de todos. Es con Dios con quien tiene que comunicarse, y hablar de él en los escasos tiempos señalados en las Constituciones para tratar con los demás. Así la vida de comunidad será "vida perfecta y de gran utilidad". Porque si Dios está donde hay dos o tres (Mt 18,20), “¿cuánto más dará su favor a todo un convento, donde hay tantos siervos de su Majestad [...], siendo unos en amor y caridad"159.

\section{b) Paciencia y humildad}

El trato con los demás es un tormento. La comunidad es un campo de prueba, un picadero en el que el religioso se ejercita y le ejercitan. "Toda criatura es verdugo atormentador"; "llena de siniestros y trabajos" está la

Cor 5, 15) (Ib., ib. 43, 70). Otros exámenes de conciencia en Soliloquios I, cs. 8-14, ns. 15-26; Sermones, 229 (Denis 6), 3.

158. Regla de vida cristiana, documento II, II, 363.

159. Regla, 1, 5-6. 
vida activa; "no pequeña cruz es el amor del prójimo". Son algunas de las expresiones que han aparecido en los textos citados del beato, indicadoras de lo enojoso que les resultaba, a él y a todos, el relacionarse con los demás, aun cuando fuera por amor de Dios. Con los demás hay que tener paciencia, sufrirlos, sobrellevarlos, humillarse ante ellos. "Ten por averiguado, avisa san Juan de la Cruz, que en los conventos y comunidades nunca ha de faltar algo en que tropezar, pues nunca faltan demonios que procuren derribar los santos, y Dios lo permite para ejercitarlos y probarlos"160. El ejemplo de los ciervos, recordado por san Agustín, que, según se decía, se apoyan unos a otros al pasar una corriente ${ }^{161}$, lo propone también el beato, de modo que las flaquezas del prójimo lleguen a sernos "dulces y no penosas; nos den recreación y no pesadumbre y trabajo"162. La soberbia y la ira siempre andan en pleitos y debates. "La paciencia y la humildad son dos hermanas muy queridas y que jamás se apartan una de otra [...]. Considerad, sierva de Jesucristo, estas dos virtudes que el Señor quiere que aprendáis de él, que son mucho menester para la religión: sed paciente y muy sufrida con todas y mirad que vuestro Esposo Cristo es cordero mansísimo [...]. Luego la esposa suya, a quien ha de amar y consolar cordera ha de ser paciente y muy sufrida [...]; paloma suya, mansa, sin hiel de ira y ave que gime cantando y canta gimiendo"163. El religioso no debe rehuir las pruebas. "Demandadle paciencia para sufrir injurias; pedidle humildad, pues le veis tan humillado; suplicadle que os dé su cruz y fuerzas para llevarla, que estas son las más excelentes mercedes que hace en esta vida a los suyos"164. "Fuera de camino vamos huyendo la humillación, que es la persecución, injuria y maltratamiento [se trata de persecución, injuria y maltratamiento dentro del convento] que nos hacen, pues ella es la escala para subir a la humildad. Queremos ser humildes y apartámonos del camino que guía a la humildad [...]. La humildad fuerte es, paciente y sufrida es, que aun quejarse no sabe y muy menos vengarse; aunque si bien lo miramos, el quejarse uno parte de venganza es y no pequeña"165. "Lo que el mundo llama honra o buena crianza, llamamos en la religión humildad, con la cual pertenece tener a todos en mucho [...]. Prevenir cada uno a otro con crianza es andar a porfía sobre cuál comenzará primero para que así obligue al otro a ser humilde y bien criado"166

160. Cautelas, 9.

161. Cf. Comentarios a los salmos, 41, 4.

162. Epistolario cristiano, 9, I, 169; cf. Tratado del sacramento de la penitencia, 10, I,336.

163. Epistolario cristiano,. 6, I, 111-112.

164. Ib., 118.

165. Ib., 110

166. Regla, 1, 18 . 
c) Enfermos y huéspedes

Paciencia y humildad hay que tener de manera muy especial con los enfermos y huéspedes, la clase privilegiada del monasterio. La enfermedad es un don de Dios, un gran don. El enfermo es el gran amigo de Dios. Como a tal hay que tratarle. Entresaco un solo texto de los muchos que hay. "Principalmente, le dice a su hermana casada, debéis de tener diligencia, en que sean consolados los enfermos, porque allí más resplandezca la caridad. No es pequeña merced de Dios tener el hospital de la puerta adentro para ejercitar las obras de misericordia con los enfermos"167.

\section{d) Modestia}

El religioso ha de andar con modestia, también en el convento. La compostura debe ser su hábito en todo tiempo y lugar, acompañado o solo, porque, aunque no le vea nadie, le está viendo Dios. Norma: "bajad vuestros ojos mirando a la tierra, pues sois tierra [...]; traer bajos los ojos [...]; los ojos inclinados en tierra"168. Es norma que los jesuitas conocían muy bien. En el proceso de beatificación de Orozco, varios testigos destacan su "gran compostura, mortificación y modestia"169.

La modestia debe subir puntos cuando el religioso tiene que tratar con mujeres. "De mirar Eva la fruta vedada nos vino todo el daño y perdición a nosotros. No es bien mirar lo que no es lícito desear"170. De san Luis Gonzaga se leía, en las lecciones del Breviario anterior al Vaticano II, que fue un ángel en carne humana, pues el amor de Dios le había absorbido el cuerpo. Tan modesto que no conoció a su madre, pues no la vio nunca. Este último extremo, tan ponderado en siglos anteriores, en los que la modestia conoció sus horas más altas, desapareció ya en las últimas ediciones, desde 1961 al menos. En el Oficio de Lectura actual ni rastro de esta virtud. Del beato Alonso de Orozco dice un testigo en el proceso de beatificación que, "advertido por otros para que le observase", vio el arte con que "se daba la vuelta, volviendo casi los hombros para no mirarlas a los ojos"171. Sabidas son las precauciones que san Agustín tomaba en su trato con las mujeres, incluida su herma-

167. Regla de vida cristiana, documento III, II, 376 .

168. Epistolario cristiano, 6, I, 112-113.

169. Carlos ALONSO, art. cit., 362 y 368.

170. Regla, 3, 6 .

171. Carlos ALONSO, art. cit., 378.

172. Cf. POSIDIO, Vita, XXVI. 
na172. Y es que, como dice un texto ya citado, "celoso es vuestro Esposo, y aun el alzar de ojos con curiosidad mira con aviso", y de él lleva cuenta.

\section{e) Desentenderse de los demás}

Tapie el religioso sus sentidos, y viva emparedado, enamorado de su Esposo, únicamente de él. No ande fisgoneando por el convento; estése en su celda, atento a su alma y a Dios; a nadie más. No se entrometa en vidas ajenas, ni se preocupe de los asuntos de la comunidad, a no ser que tenga en ella algún oficio. Recuérdense los consejos de san Juan de la Cruz y de santa Teresa de Jesús a este respecto.

"No teniendo oficio de prelado, solamente miréis vuestras faltas y quitéis los ojos de los descuidos ajenos. Es tan grande la envidia del demonio y tanta la curiosidad de algunos en la religión que olvidan sus defectos y ni miran ni hablan sino de los ajenos. Esto estorba mucho el aprovechamiento en el camino del espíritu. Por tanto, hemos de decir con David: velaré sobre mi guarda propia. Y creedme que tanto se entiende haber un alma aprovechado cuando se hallare sorda y ciega para negocios ajenos y entendiere en los propios, encomendare a Dios las faltas de los hermanos y trabajare de enmendarse a sí misma"173.

\section{f) Contiendas y reconciliación}

En el monasterio habrá, a pesar de todo, contiendas y pleitos. Deber del buen religioso es no permanecer en la ira y reconciliarse cuanto antes, así como corregir a sus hermanos. De todo esto habla en sus libros, en especial en sus comentarios a la Regla de san Agustín.

\section{g) Amistad}

Y ¿qué decir de la amistad? El beato habla de ella, pero en térmios tan generales, que no la diferencia en nada del amor espiritual o caridad con que hay que amar a todos los hombres.

“¿Qué cosa más natural y más asentada en razón que amarse los hombres unos a otros, hacerse tratamiento de hermanos y tenerse gran amistad? ${ }^{174}$. A

173. Epistolario cristiano, 6, I, 126.

174. Arte de amar a Dios y al prójimo, 12, I, 244. 
los amigos hay que amarlos en Dios, por Dios y para Dios; en gracia de Dios y para que sean nuestros compañeros en la gloria. "Habéis de amar a los enemigos y amigos; a los unos por Dios, que lo manda así; y a los otros en Dios, porque ni a vuestro propio padre habéis de amar sino en Dios"175. "Si queremos saber qué cosa es caridad, es un amor o amistad con la cual amamos a Dios por sí mismo y al prójimo por Dios. Este amor cría Dios y le infunde en nuestra alma, levantándola de la afición de las cosas terrenas y poniéndola en lo que siempre ha de durar, que es lo eterno"176.

La amistad fundada en motivos humanos era para ellos vitanda. No es preciso citar los numerosos pasajes de santa Teresa de Jesús contra las amistades particulares, bien arropados po una larga tradición. Y ¿a qué queda reducida una amistad si no es particular?

Amigo es Dios y amigo es Jesucristo. "El amor más alto y más fino y que no puede subir más en quilates es este que llaman los doctores amor de amistad, el cual consiste en un solo punto, amar a Dios, sin otro respeto más de porque es bondad soberana, santidad eterna y sabiduría no limitada"177. "Condición es de la amistad y ley que ella inviolablemente guarda manifestarse los pensamientos y corazones entre los amigos que con leal y virtuoso amor se aman [...]. El amigo es otro yo, y como a mí mismo nada es oculto de lo que pienso, tampoco lo ha de ser al amigo que con verdad amo"178. El amigo es el confidente; pero ¿de qué secretos? De los secretos de un alma ordenada en la caridad, que se confía a otra alma en las misma condiciones. Tal amigo solo es Dios. "Como nuestro Dios sea tan Padre y tan amigo nuestro, la ley de amistad nos obliga a comunicarle los secretos de nuestro corazón, porque no se queje de nosotros, como se quejó de los malos por Isaías: han hecho concilio sin mí y no por mi parecer (Is 30,1)" 179. El amigo es el consejero nato. "Allá dijo el filósofo que la amistad entre los hombres era en gran manera menester. Y dijo muy bien, porque no solo para el contentamiento y descanso de los trabajos que esta vida breve y penosa trae consigo, mas aun para recibir consejo en muchos casos arduos es menester tener amigo sabio, bueno y poderoso [...]. ¿Quién es el que todas estas condiciones tiene, sino el que nos amó hasta dar la vida en la cruz por nuestro remedio?"180.

¿Amistad entre los religiosos? ¿Cómo sería posible en estas condiciones? $\mathrm{Ni}$ entre los religiosos ni, mucho menos, de estos con los seglares. Oigamos a

175. Regla de vida cristiana, documento 5, II, 386.

176. Historia de la reina Sabá, 8, III, 299.

177. Íb., 9, III, 302.

178. Íb., 20, III, 341.

179. Íb. íb.

180. Epistolario cristiano, dedicatoria, I, sin paginación. 
san Juan de la Cruz: "No ames a una persona más que a otra, que errarás, porque aquel es digno de más amor que Dios ama más, y no sabes tú a cuál ama Dios más. Pero olvidándolos tú igualmente a todos, según te conviene para el santo recogimiento, te librarás del yerro de más y menos en ellos. No pienses nada de ellos, no trates nada dellos, ni bienes ni males, y huye de ellos cuanto buenamente pudieres. Y si esto no guardas, no sabrás ser religioso, ni podrás llegar al santo recogimiento ni librarte de las imperfecciones"181.

Se suele asociar con la amistad el nombre de san Agustín. En un libro póstumo de Lope Cilleruelo, se hacen algunas observaciones muy certeras sobre los límites de esta amistad, aunque al final termina admitiendo en san Agustín la amistad puramente humana y los valores exclusivamente huma$\operatorname{nos}^{182}$. No creo que este fuera el criterio del santo. Los textos ya dados sobre las supuestas virtudes de los paganos y otros muchos que se pudieran aducir son suficientemente claros.

Las cosas percibidas por los sentidos, dice a propósito de la amistad, ni por un instante permanecen en el ser: no son. La auténtica filosofía nos prohibe amarlas. Solo así podrá el alma orientarse hacia lo eterno. En mi mente, le escribe a un amigo, te veo tal como eres en tu ser auténtico, "verdadero y simple; tal como puedes ser amado sin preocupación", es decir, con amor espiritual, eterno. Esto es lo que hay que amar y solo esto. Pero la realidad es muy distinta. "Cuando te alejas, te confieso que busco y deseo, en cuanto es lícito, tu compañía y vista. Sé de sobra, si es que te conozco, que te agrada este vicio mío, y temes que tus amigos se curen de él [...]. Si por ser tan fuerte, eres ya capaz de percatarte de que esto es un lazo, y te burlas de los que están presos en él, no presumas de ser mejor y distinto. Ciertamente yo, cuando deseo al amigo ausente, quiero que él, a su vez, me desee. Vigilo, sin embargo, todo lo que puedo, y me esfuerzo por no amar nada que se me pueda arrebatar contra mi voluntad"183. "No existe amistad verdadera sino entre aquellos a quienes tú aglutinas por medio de la caridad"184. "La amistad trae nombre de amor y nunca es fiel sino en Cristo, en quien únicamente puede ser eterna y feliz"185.

Agustín se debate entre la teoría y la práctica. Su análisis de la amistad es exacto. Desea la presencia del amigo, y se esfuerza porque así sea. Luego ama en el amigo lo particular y concreto, lo transitorio, la presencia corporal. Sabe, sin embargo, que esto es un vicio; que no tiene que amar nada que le

181. Cautelas, 6.

182. Cf. Comentario a la Regla de san Agustín, Estudio Agustniano, Valladolid 1994, $169-$ 170.

183. Cartas, 2.

184. Id., Confesiones, IV, $4,7$.

185. Id., Contra las dos cartas de los pelagianos, I, 1. 
pueda ser arrebatado. El alma debe refugiarse en su interior y amar ahí el verdadero ser del amigo, contra el que nada podrá la muerte. Al describir su vivencia de la amistad es admirable; al teorizar sobre ella, recae en el neoplatonismo, y se pervierte; y en su perversión arrastró a los que vinieron después. La amistad quedó reducida al amor de caridad, a lo común y público. La verdadera amistad, la que se funda en lo partucular y privado, quedó proscrita. Fuera de la Iglesia católica, la amistad, como la virtud, no es amistad sino su similitud. No hay valores humanos. Augustinus dixit.

Muy acertadamente, Jordán de Sajonia, en el libro citado, Vitasfratrum, al hablar de la comunión de los bienes temporales entre los religiosos, es decir, de la pobreza, la extiende a los bienes espirituales. Entre ellos no debe haber nada propio; todo ha de ser común. "Y no tengáis nada propio, sino que todo os sea común"186, dice la Regla.."Según Platón, comenta él, está justamente ordenada la ciudad en la que nadie conoce afectos propios"187. Ya tenemos la norma de la vida común: el estado totalitario platónico, el comunismo. Leamos La república, y desechemos el Evangelio. Fuera los afectos propios, privados; fuera las ideas propias, los gustos particulares, las convicciones personales; fuera las discrepancias. Todo común, público. Entonces habrá en la comunidad unanimidad y concordia (también en los cementerios). Entonces reinará Dios en la comunidad; será su alma, su única alma.

Pero la unidad y concordia de una comunidad humana tienen que ser creadas mancomunadamente, no impuestas; creadas por personas y para personas, con absoluto respeto a las diferencias dentro de la unidad. "El precepto existió por el hombre, no el hombre por el precepto; luego señor es el Hijo del hombre también del precepto" ( Mc 2, 27-28 par).

Cuando nos encontremos en los textos de los espirituales del pasado con la palabra amistad, cuidemos de no poner en ella nuestro significado, sino el que ellos le daban.

\section{h) El silencio}

El pez vive en el agua; el religioso, en el silencio. Y aquí sí que se llenarían muchas páginas con lo que el beato dice sobre este particular. La doctrina está dispersa en todas sus obras y le dedica, además, una obra entera, Guarda de la lengua.

186. Id., Regla, I, 4.

187. Jordani de Saxonia, Liber vitasfratrum, ediderunt Rudolphus ARBESMANN et Winfridus HÜMPFNER, New York 1943, tertia pars, c. 1, 322. En nota dan la cita de las obras de Platón en que aparece esta idea, junto con las de otros autores mencionados por Jordán de Sajonia. 
Y ¿de qué puede hablar el religioso? No de asuntos humanos; tampoco de los secretos que Dios le comunica, pues no le volvería a comunicar más. Secretum meum mihi (Is 24, 16), se leía en la Vulgata. Era norma de recta espiritualidad. Calle, pues, a ejemplo de Jesucristo en la pasión, y hable solo cuando lo exija la necesidad de la caridad, y aun entonces parcamente. Así nada le turbará la paz.

"El religioso que es humilde y amador de silencio no da lugar a disensión ni contienda alguna; luego se deja vencer sujetándose al parecer ajeno"188. El religioso "en su monasterio se encerró para hablar siempre con Dios"189. Señal de humildad es "hablar poco y con provecho, cuando lo pide la necesidad del prójimo y la caridad"190. El segundo grado de humildad "es hablar pocas palabras y estas según razón y sin voces"191. "Adorne su boca con el joyel del silencio [David pedía un "postigo de circunstancia" para sus labios ]. Admirable oración es esta y mucho la habían de frecuentar las personas religiosas [...]. Callar a su tiempo y hablar cuando es menester"192. Hay tiempo de callar y tiempo de hablar. Callar "para levantarse sobre sí misma a las cosas celestiales" y hablar en alabanzas divinas, confesión de los pecados y consolación de los afligidos. Todo otro hablar es "ocupación miserable de la carne" y apacentar "los cabritos mal sosegados", que "son los apetitos diversos del alma acerca de las honras, intereses y pasatiempos mundanos", que serán puestos a la izquierda de Cristo y enviados al fuego eterno' ${ }^{193}$. Si Santiago dice que "el cristiano que trata en el mundo sus negocios ha de hablar tasado y con utilidad suya o del prójimo, so pena de ser vana su cristiandad si se desmandare a hablar superfluamente con ofensa de Dios notable, ¿qué diremos de la religiosa encerrada y dedicada a Dios, sino que siempre piense cosas celestiales, hable de Dios y trate cosas muy buenas y santas"194. "Los santos fundadores de las Órdenes reformadas hicieron tan gran fuerza en que se guardase [silencio] en ciertas horas y tiempos para que los siervos de Dios, estando a solas, se ejercitaran en la lección santa, en la oración y contemplación"195. "Dios no nos hace mercedes porque luego damos pregón"196."Hable poco, aconseja san Juan de la Cruz, y en cosas que no es preguntado no se meta"197.

188. Regla, 5, 2.

189. Epistolario cristiano, 5, I, 106.

190. Epistolario cristiano, 6, I, 112.

191. Ib., 113.

192. Ib., 115.

193. Ib., ib.

194. Desposorio espiritual, 4, II, 447.

195. Guarda de la lengua, 3, III, 416.

196. Monte de contemplación, 13, II, 163.

197. Dichos de luz y amor, 140, edic. cit., 419. 
Hoy suelen decir los que a estos asuntos se dedican que en las comunidades religiosas se debe guardar silencio "por caridad", y se asombran, un tanto despectivamente, de las razones que en el pasado se daban. ¡Curioso! Porque en el pasado se daba la misma razón: "por caridad". Tan simple expresión es como un ventanal que nos permite ver dos paisajes enteramente distintos, y percatarnos de lo que va de ayer a hoy. "Por caridad" significa hoy "por los demás", "en atención a los demás". Ayer, en cambio, significaba "por Dios", para no perturbar el recogimiento en Dios que debe reinar en el monasterio. Podríamos discurrir igualmente sobre lo que va de ayer a hoy contrastando esta doctrina sobre el silencio con la que corre actualmente sobre el diálogo en las comunidades religiosas, aunque me parece que muchos de sus propagandistas no se han enterado de qué va, y se limitan a repetir lo que está de moda.

¡Cuidado con las palabras ociosas! Las dañosas ni mencionarlas. "Tampoco somos nuestros para hablar. Aviso es que el Señor nos da para que la lengua, leona brava, se encierre y se ate, de toda palabra ociosa que hablaren los hombres darán cuenta el día del juicio (Mt 12,36). Llama aquí palabra ociosa la que se habla sin provecho del que la dice o del que la oye [...].No solamente tiene cuenta con las obras, mas aun con los pensamientos y palabras [...]. No somos nuestros para pensar, hablar ni obrar lo que nuestra voluntad mala quiere, sino lo que manda en su ley el que nos crió y compró para su servicio, Cristo nuestro Señor"198. "Si de la palabra ociosa, que es sin provecho hablada habrá estrecha cuenta, de la murmuración y de las palabras dañosas ¿qué juicio se hará?"199. Recordemos aquel texto ya dado: "celoso es vuestro Esposo y cada palabra os cuenta". "¡Qué vidrio tan delicado es una alma temerosa de Dios, pues la llama su Esposo flor de azucena, y bien flor, porque aun una culpa venial basta a darle pena y un polvo de una palabra ociosa le da tan continua guerra [...].jCuán tierna será una conciencia, adonde mora el Espíritu santo, pues dijo ser semejante a la niñeta de los ojos!"200 Ejemplo de silencio y de hablar con provecho, como de todas las virtudes aquí tratadas, fue la Virgen. "Su lengua nunca habló una palabra ociosa"201.

198. Epistolario cristiano, 2, I, 28.

199. Desposorio espiritual, 4 , II, 447.

200. Monte de contemplación, 13, II, 160.

201. Tratado de la corona de Nuestra Señora, 11, párrafo 1, III, 164. 
i) La celda

Después de todo lo dicho, nada tiene de extraño que el buen religioso ame su celda, tema de gran arraigo en la literatura monástica. La celda es su oratorio particular.

"En el oratorio (que es la celda), nadie ha de hacer otra cosa sino aquello que suena su nombre [...]. No ha de haber ruido ni golpes que inquieten a los que hablen con Dios. En el lugar santo ha de ser el ejercicio santo"202."Gran temor debe tener el religioso si anda vagabundo por el monasterio y si murmura de sus hermanos, andando de celda en celda, no le diga el Señor lo que a los mercaderes del templo dijo"203. También los seglares deben tener en su casa un oratorio, donde se retraigan a dar gracias al comenzar el día, y por las noches a examinar su conciencia y practicar sus devociones 204 .

\section{j) Recreo y conversación}

Pero el arco no puede estar siempre tenso; hay que dejarle algún tiempo en reposo (es la imagen que ellos usaban). Frailes y monjas tenían sus ratitos de solaz y esparcimiento. No muchos, si nos atenemos a lo que enseñaban los maestros, y señalaban las Constituciones, y pefectamente controlados. Lo del arco en reposo era muy relativo. La espontaneidad en el trato, valor inapreciable, estaba condenada. Había que estar siempre en guardia, en vela sobre uno mismo y sobre los demás; no apartar el pensamiento de Dios, pues cualquier otro pensamiento le despierta los celos. Toda recreación, dice el beato, es aborrecible. Cristo desde el cenáculo se fue a orar a Getsemaní. Aprenda el religioso lo que tiene que hacer después de comer y cenar.

"Nuestras fiestas y pasatiempos vanos jamás faltan, siempre se halla oportunidad para pecar, mas el tiempo de Cristo pocas veces tiene sazón"205. El amor propio que Dios manda, amarás a tu prójimo como a ti mismo, no consiste en que "uses contigo en bien comer y beber[...]; no tampoco en buscar pasatiempos y regalos"206.

A los seglares les recuerda que "como cristianos consideren que la vida y pasatiempos (aunque lícitos) pasan muy presto"207. Por esto, como prepara-

202. Regla, 2,6.

203. $I b ., 2,2$.

204. Regla de vida cristiana, documento 1, 358, y documento 6, 394 .

205. Ib., 6, III, 240.

206. Historia de la reina Sabá, 9, III, 305. 
ción para la comunión deben "apartarse aun de los regalos y pasatiempos lícitos y sin pecado"208. Deben fijarse un horario. "Lo que yo querría es que taséis vuestro tiempo de manera que lo menos de él gastéis en vuestra recreación y pasatiempo. Lo menos del manjar es la sal y así lo menos del tiempo habéis de tomar para vuestro pasatiempo, aunque lícito, porque vuestra vida cristiana sea sabrosa a Dios y suave a vuestros vasallos"209.

En los religiosos, "los cabritos mal sosegados son los apetitos diversos del alma acerca de las honras, intereses y pasatiempos mundanos"210. "Los mancebos que dejó Abrahán al pie del monte son los deseos de mocedades, riquezas, pasatiempos y honras, los cuales se han de dar de mano para obedecer a Dios"211. El religioso debe permanecer en su celda en trato con Dios. "Séale aborrecible toda recreación, a la cual llama san Bernardo distracción. ¡Oh cuán delicada es la consolación divina y no se da a quien busca otra!"212. "Acabada la comida, a imitación de nuestro Salvador, que después de cenar llevó a sus religiosos a orar, no os deis a pláticas sin provecho, porque este tiempo es en el que más peligro tiene nuestra lengua. Gran aviso es el del siervo de Dios: hablar cosas tan santas y provechosas en todo tiempo, que jamás por la recreación corporal pierda el espíritu su consolación"213. Del cenáculo Cristo se fue a Getsemaní a orar. "Luego el bocado en la boca los llevó a orar, porque conozcáis, alma mía, que no hay tiempo que no se debe ofrecer a la oración. Aquí se deben afrentar las personas que dicen ser después de comer o cenar tiempo de holgar un rato en palabras ociosas. Y lo que es peor, que, por su tibia vida y mala costumbre, dicen que no se puede vivir la vida sin esto y que conviene mucho a la salud del cuerpo. No sigas, alma mía, estos discípulos de Avicena y Galeno. Mira el médico de tu salud Cristo, y a sus apóstoles, a qué tiempo y hora van a orar. No reposan sobre la cena; luego se parten de la ciudad para hablar con Dios en la oración"214.

De Orozco dice un testigo en el proceso de beatificación que, aunque los otros religiosos, "estaban al sol en conversación, él por no parecer que se extrañaba, estaba con ellos cosa de medio cuarto de hora, poco más o menos, siempre en pie"215. "Siempre en pie, dice otro, y quitando la capilla por el res-

207. Tratado de las siete palabras que María santísima habló, 6, III, 238.

208. Tratado del sacramento de la penitencia, examen para la comunión, I, 369.

209. Regimiento del alma, suma del tercer aviso, II, 430.

210. Epistolario cristiano, 6, I, 115.

211. Tratado de las siete palabras que María santísina habló, 7, III, 252.

212. Tratado del sacramento de la penitencia, 16, I, 353.

213. Desposorio espiritual, 7, II, 453-454.

21.4. Vergel de oración, 1, II, 2.

215. Carlos ALONSO, art. cit,. 378. 
peto y la reverencia que tenía de nuestro Señor, con quien hablaba"216. ¡Medio cuarto de hora y esto por no parecer esquivo; siempre en pie, dispuesto a marchar y hablando con nuestro Señor!

La conversación de un cristiano debe ser siempre espiritual. Seglares y religiosos deben apartarse "de conversaciones mundanas" 217 . "No te vayas, alma mía, de ti misma, vagueando por los pensamientos, sin provecho, ni estéis del todo atenta, cuando casi por fuerza para cumplir con los otros, estés ocupada en conversación. Hurtar te puedes delante de todo el mundo y estar dentro de tu corazón, acompañando allí al bendito Esposo Jesús, aun en todo ejercicio corporal no superfluo. Bien sé que te espantará esta sentencia, pareciéndote casi imposible; mas cuando el Señor te hiciere merced tan crecida que lo sientas por experiencia, entonces verás con verdad que haber vencido este contrario tan grande que es toda superflua ocupación convenía mucho para ver las grandes misericordias de Dios y sus consolaciones"218.

Moderadas y santas de manera especial deben ser las conversaciones antes y después de la comunión. “¿Qué pureza, qué santidad es razón que tengan y qué conversación tan angelical habían de ejercitar los sacerdotes y cristianos que van a tal mesa y a ser convidados a un manjar y plato con los ángeles"219. Después de la comunión, por todo el día "no dejar la compañía y conversación con nuestro Rey Jesucristo"220.

Los religiosos están muertos al mundo; ya no conversan con los vivos. "Muertos sois al mundo y vuestra vida está escondida con Cristo en Dios (Colos 3, 3). Gente muerta al mundo, olvidada de todos, como lo son los muertos, que ya no conversan con los vivos [...]. Considere cómo guarda su corazón de todo malo pensamiento, su lengua de toda palabra seglar y su conversación si es distraída y no con personas de espíritu"221. Su conversación ha de estar en el cielo, repite el beato, y así exhalarán el buen olor de Cristo. "Nuestras palabras religiosas y espirituales son como hojas de laurel, que no poco agradan a los ángeles"222

Con especial cuidado deben mirar por la castidad en sus conversaciones. "Retraeos en vuestro monasterio; huid de conversaciones peligrosas; huid de todos y huid de vos mismo. Azucena es entre espinas el alma pura y casta. $\mathrm{Y}$

216. Id., ib., 370.

217. Regimiento del alma, aviso primero, II, 419.

218. Memorial de amor santo, 6, II, 186-187.

219. Tratado de la suavidad de Dios, 21, II, 515.

220. Ib., ib., 518.

221. Tratado del sacramento de la penitencia, 16, I, 352.

222. Regla, 7, 35. 
entre espinas se ha de guardar y fortalecer con ayunos, con disciplinas, con guardar los sentidos todos y con jamás aflojar en la oración"223.

La así llamada "recreación corporal" consistía, lo acabamos de ver, en hablar de cosas santas. "Después de comer y cenar, llegaos a personas ancianas de espíritu, que hablen cosas de Dios y del menosprecio del mundo"224. Tal recreación, según santa Teresa, servía "de entender allí las faltas de las hermanas y tomar un poco de alivio para llevar el rigor de la regla"225..

Cuidado especial debían tener, ya he dicho por qué, en apartar de su pensamiento y, por consiguiente, de su plática, el tema de los linajes. La advertencia va dirigida muy especialmente a las religiosas. No ha de haber en ellas "memoria de linaje terreno, ni plática que suene a esto, que es gran falta de espíritu y trato seglar y no de religiosa"226. Tampoco debe haber entre ellas marisabidillas. La esposa de Cristo no debe tener "presunción de sabia y bien hablada, porque estas son reliquias de Babilonia y entibian el amor de Dios [...]. Guárdeos Dios de llevar al monasterio idolillos, presunción y respetos de honra"227. También santa Teresa quería en sus monjas hablar simple y llano, "estilo de ermitaños y gente retirada", que no usa "vocablos de novedades y melindres"228

Para evitar que la conversación fuera por derroteros indebidos San Juan de la Cruz ideó un nuevo oficio en la comunidad religiosa: el alguacil de conversación. Cuando esta se desviaba, el alguacil se hinojaba, y todos quedaban amonestados 229 .

Prácticas parecidas para ahuyentar las conversaciones no religiosas continuaron hasta nuestro siglo. Un jesuita cuenta la vida de los misioneros durante el viaje en barco y el extravío moral de los pasajeros. “¡Ah, y con frecuencia aflige el espectáculo de frailes que fuman y se sientan subiéndose el sayal, cruzando las piernas ingle contra ingle.- En casa -le interrumpió un padre de los viejos- ya no hay colegial que ponga una pierna encima de la otra. ]...]. El padre Martí, gordezuelo y pálido, apartó los doloridos asuntos estampándose una palmadita en la frente"230

223. Desposorio espiritual, epístola a un religioso, II, 462.

224. Ib., 4, II, 447-448.

225. Fundaciones, $13,5$.

226. Epistolario cristiano, 6, I, 114.

227. Ib., ib.

228. Visita de descalzas, 42, tema estudiado por Menéndez Pidal, al que le ha añadido algún matiz Víctor García de la Concha.

229. cf. José Vicente RODRÍGUEZ, San Juan de la Cruz y su estilo de hacer comunidad, en Confer 31 (1991) 58-59; Id., Florecillas de san Juan de la Cruz, Madrid 1990, 115-116.

230. Gabriel MIRÓ, El obispo leproso, c. I, en Obras escogidas, edic. cit., 804. 


\section{k) Risa y juegos}

Dos avisos que no hay que olvidar. El tercer grado de humildad es "no ser fácil para la risa" 231. "Cuando estuviere alegre, aconseja Santa Teresa, no sea con risas demasiadas, sino con alegría humilde, modesta, afable y edificativa"232. "Fue amigo de recogimiento y de hablar poco, se dice de san Juan de la Cruz; su risa poca y compuesta"233. La risa fue siempre mal vista por los espirituales. Era señal de que el pensamiento se habia apartado de Dios. También lo era el juego. Por eso lo condenaban con la misma energía, a pesar de la escasa clientela que conseguían con sus prédicas. "También se acuse, le dice a un seglar, del tiempo mal empleado en los días de fiesta, en juegos o en ejercicios vanos o peligrosos, declarando cada cosa"234; "si en juegos vanos gastó las fiestas"235. A una joven se le apareció la Virgen rodeada de vírgenes, cuenta san Gregorio Magno, y le preguntó si quería estar con ellas. Como esta respondiera que sí, le dijo la Virgen: "pues apártate de conversar con otras mozas, no trates en juegos ni risas y de aquí a treinta días vendré por ti"236. Santa Teresa usa alguna vez el ajedrez como metáfora, pero advierte a sus hijas: "Ansí me habéis de reprehender, porque hablo en cosas de juego no le habiendo en esta casa ni habiéndole de haber. Aquí veréis la madre que os dio Dios, que hasta vanidad sabía; mas dicen que es lícito algunas veces"237.

\section{1) Vida eremítica}

El religioso vive en soledad, en soledad con Dios. Tal querencia debe tener por la soledad que, en el monasterio, debe vivir preparando su partida para el desierto. Después del Concilio de Trento, esto era solo un recuerdo de tiempos. idos; pero quedaba el espíritu, y quedaban las ermitas dentro de la cercas de los monasterios, adonde podían recogerse los apretados del fervor. La venerable tradición monástica enseñaba que la vida eremítica era la forma más perfecta de vida religiosa. Lo enseñó también santo Tomás. A más soledad y contemplación, más perfección. Sabio, decían los estoicos, perfecto,

231. Epistolario cristiano, 6, I, 113.

232. Avisos, 24, 664.

233. Testimonio del P. Eliseo de los Mártires, en san JUAN DE LA CRUZ, Obras Completas, Madrid, EDE 1988, 1101-1107.

234. Tratado del sacramento de la penitencia, 10, 1, 321.

235. Ib., Ib., 343.

236. Victoria de la muerte, 33, I, 556.

237. Camino de perfección, $E, 24,1$. 
dijeron los monjes, es quien se basta a sí mismo. El muy dado a Dios deja toda otra "compañía y conversación". La comunidad es tan solo una escuela donde los soldados se entrenan para la lucha cuerpo a cuerpo con el demonio en el yermo. Los Padres del Yermo fueron considerados siempre como el ideal de la vida religiosa. Tal concepción se acentuó en el siglo XVI con los movimientos de reforma en las Órdenes religiosas. De niños, santa Teresa de Jesús y un hermano suyo jugaban a ermitaños

El deseo de ser pobres con Cristo "pobló los desiertos de Egipto de aquellos santos Padres"238."No podemos negar que la vida solitaria sea más perfecta, porque hay más aparejo para darse el religioso a la contemplación [...]. Mas a la verdad no se habiendo muchos años ejercitado en la religión, adonde se perfeccionan las virtudes todas, mayormente la paciencia, engaño sería querer morar en el desierto solo. [... San Jerónimo dice]: queremos que del nido de la religión y conventualidad vuelen los religiosos al desierto. De manera que para ser varón perfecto ha primero de vivir vida común y conventual, porque así sea hábil de vivir vida solitaria, la cual pertenece a los ya perfectos y no a los principiantes. Aunque verdad es que en el monasterio los varones acabados edifican para sí desiertos y soledad, retrayéndose y apartándose, como si en el desierto morasen solos. Gran sentencia fue aquella del filósofo: el que no comunica con otros es bruto animal o es Dios. Quiere decir que el tal o lo hace de rústico y salvaje o porque es hombre divino y muy dado a Dios, por quien deja toda compañía y conversación"239.

El Dios aristotélico se piensa a sí mismo. Entrar en comunión con los hombres sería negar su ser. Pero este Dios ¿tiene algo que ver con las tres personas de la santísima Trinidad? ¿Tiene algo que ver con el Padre, que se nos ha revelado en Jesucristo, "Palabra, [que] se hizo hombre y acampó entre nosotros?" (Jn 1, 14). El Dios de Jesucristo ¿es un Dios solitario o un Dios conviviente?

\section{m) Los agustinos}

Todo lo dicho debe hacerse realidad, de manera muy especial, en los agustinos. Tal como entonces se creía, el beato escribe que san Agustín fue ermitaño y fundador de ermitaños, de la orden a la que él pertenece. En sus obras cita como de San Agustín los apócrifos Sermones ad fratres in eremo.

238. Epistolario cristiano, 5, II, 97.

239. Instrucción de religiosos, 7, 64 . 
Ermitaño debe ser, por consiguiente, el buen agustino ${ }^{240}$. En esta creencia se fundamentaron los diversos movimientos de reforma que en ellos hubo. Del beato cuentan varios testigos en el proceso de beatificación que quiso recogerse en el apartado monasterio de Santa María del Risco (Segovia), lo que no le permitió Felipe II'241.

\section{n) Relaciones entre los religiosos}

Después de lo expuesto, podemos preguntarnos: en la comunidad religiosa, tal como la quería el beato Orozco y la querían los maestros espirituales, ¿había relaciones entre los religiosos? La respuesta es clara: las menos posibles. El religioso se relaciona con Dios, solamente con él. En el monasterio se ha consagrado soli Deo, a estar solus cum Solo. Ninguna criatura debe ocupar la más mínima parcela de su corazón. Hay que vivir desde Dios y cara $a$ Dios, en Dios, por Dios y para Dios. Solo Dios. Cualquier afecto humano es vituperable. Cualquier relación humana, también entre los religiosos, queda condenada como tal. Un religioso así está "endiosado", como ellos decían; poseído por Dios. Vive ya aquí vida angélica, repite el beato. De su soledad sale únicamente por necesidad de la caridad, quedando su alma en soledad y volviendo a ella su cuerpo lo antes posible. Los religiosos se aman con amor espiritual, en Dios, por Dios y para Dios. Cualquier otro amor es carnal, pecado 242 . No se aman a sí mismos ni entre sí, sino a Dios en ellos. "Vivid, pues, en unanimidad y concordia, y honrad mutuamente a Dios en vosotros, de quien habéis sido hechos templos"243.

\section{ñ) El superior y la obediencia}

Hasta ahora hemos considerado las que pudiéramos llamar relaciones horizontales entre los religiosos, pero hay también relaciones verticales. A lo

240. Cf. Epistolario cristiano, 5, I, passim; ib., 6, I, passim; ib., 4, I, 76-77; Crónica del glorioso padre y doctor de la Iglesia san Agustín, Sevilla 1551, passim; Jesús Diez, La comunidad en la Forma de vivir, en Mayéutica 15 (1989) 236-240.

241. cf. Carlos ALONSO, art. cit., 361, 368 y 370.

242. En el Directorio de religiosas de la Visitación, fundadas por santa Juana Francisca de Chantal, quien, como sabemos, pasó por encima de su hijo al ir a fundar la Visitación, se lee: "Si una hermana es dulce, agradable, y yo la amo con ternura, y ella también me ama, y hay amor recíproco, ¿quién no ve que la amo conforme a la carne, sangre y sentido?

Si la otra tiene la condición seca y áspera, y con todo eso, no por el gusto que tengo, mas solo por amor de Dios la amo, la sirvo, la acudo, ese sí que es amor conforme al espíritu, porque no tiene en él parte la carne" (cit. por Gabriel MIRÓ, El obispo leproso, c. IV, en Obras escogidas, edic cit., 881).

243. San AGUSTÍN, Regla, I, 9. 
largo de estas páginas nos ha salido ya alguna vez, rauda, pero vigorosa, la figura clave del monasterio: el superior. Las relaciones entre los religiosos tienen que pasar por él, y por él tienen que estar supervisadas en todo momento. La obediencia es mejor que todos los sacrificios. Por ella se quema en honor de Dios la propia voluntad sin reservarse nada. Es un holocausto.

"En el sacrificio muere la carne ajena; y en la obediencia deguiéllase la propia voluntad, holocausto muy agradable a Dios [...]. Negando nuestra voluntad por el voto de la obediencia, adonde del todo nos ofrecemos a él"244. Por la obediencia, el religioso se despoja de su voluntad, se desuella vivo. "Como un san Bartolomé desollado de pies a cabeza, aun de su propio querer, no solo por lo malo, mas aun para lo que es bueno, anteponiendo en todo la voluntad de su prelado a la propia y diciendo con verdad en todo lo que hiciere: así como mi Padre me lo mandó lo hago (Jn 14, 31)"245. "Donde hay mayor dificultad es en dejarse el hombre a sí mismo, no tener querer ni parecer en la religión, resignándose todo en la voluntad de sus prelados por Dios [...]. Es necesario que los que en ella viven sean guiados, instruidos y ejercitados por un prelado, cuya voluntad sea como norte adonde los religiosos miren, negando su propio querer" 246

El religioso se queda sin querer ni parecer propios, a merced del superior en todo. Es un instrumento, un cadáver en manos de este: tal es la cima de la perfección. No consiste la obediencia en que el religioso tenga que pedir permiso al superior para moverse, sino en que no se mueva si no es mandado, lo cual es muy distinto. Ocupaciones en el monasterio, oficios, horas de silencio y de recreo, temas de conversación, rezos en común y en privado, sueño y vigilia, visitas y salidas, traslados... Todo está regulado por las leyes y en manos del superior. El religioso no cuenta para nada. Contar con él sería desviarse del camino que lleva al cielo. Con los cadáveres no se cuenta si hay que moverlos, ni ellos se mueven por sí mismos. La voluntad propia, con su libertad, es la raíz del pecado. Hay que negarla en absoluto, cercenar cualquier asomo de iniciativa. Evidente:"la obediencia religiosa no menoscaba la dignidad de la persona, sino que la lleva a su madurez", como ha dicho el Vaticano II.

"La perfección nuestra no está en ser súbditos ni en ejercitarnos en oficios bajos. Solamente consiste en una mortificación de nuestra voluntad y en una negación de todo hecha por Dios, que, como a un muerto que no resiste si le ponen en el suelo o si le asientan en un trono de rey, la obediencia haga lo que quisiere de cada un religioso"247. "La obediencia ha de ser tan pronta

244. Epistolario cristiano, 5, I, 104-105.

245. $I b ., I b ., 105$.

246. Ib., ib., 100.

247. Regla, 7, 14. 
y alegre que jamás pida razón de lo que le es mandado por el prelado [...]. El perfecto religioso no tiene mayor verdugo que su parecer. Este le trae el descontento. Este tirano jamás le deja de afligir [...]. Cese la propia voluntad y cesará el infierno [...]. Ni por un momento el religioso sea suyo ni haga su voluntad. Porque así como el pintor o el platero, en dejando los instrumentos de la mano, ellos no se menean y están como muertos, bien así el religioso que sale del querer de su prelado trabaja sin provecho. $Y$ ha de tener tan rendida su voluntad y tan mortificada que para todo se halle pronto"248. "Ya estáis muertos y vuestra vida está escondida con Cristo en Dios (Colos 3, 3). El muerto no se menea si no le menean, ni el religioso había de dar una pisada sino mandado por obediencia"249

Y esto por caridad, es decir, por amor de Dios y por amor al superior por Dios, compadeciéndose del superior, que tendrá que dar cuenta a Dios de todos y cada uno de los religiosos. No es el superior quien manda. Es Dios quien manda en él. Pero "de estos perfectos obedientes no tenemos muchos", constata el beato.

Al subir Cristo a los cielos, "déjanos prelados y guías en la tierra, a quien obedeciésemos por amor de él. [La obediencia es] camino llano y breve para ganar el cielo [...]. Nos dejó prelados en cuya voluntad renunciemos a la nuestra. No pudo ser encarecida más la obediencia que tenemos a nuestros mayores [superiores] que aquí el Señor la encareció, diciendo que él es obedecido en sus prelados [...]. Y aun también declara ser su Majestad quién es desobedecido y desacatado cuando los prelados no son obedecidos [...]. Todos son ministros de aquel sumo y único Pastor, nuestro Redentor, el cual [...] quiso morir en la cruz, siendo en todo obedientísimo al Padre, para hacer suave y dulce nuestra obediencia y que con alegría neguemos nuestra propia voluntad [...]. Con la obediencia todas las cosas son llenas de mérito, mas sin ella todas son vanas y sin fruto"250. "Dios es el que habla por nuestro prelado, como por ínterprete, declarándonos lo que quiere que hagamos; y hemos de obedecer a Dios en nuestros mayores [...]. Esta es manera y retrato de perfecta obediencia, decir a nuestro prelado: ¿que queréis, padre, que haga? No quiero estar en este convento ni en aquel; no tengo voluntad de hacer este oficio ni aquel; nada quiero ni sé querer; mandadme, que vuestra voluntad haré en todo. De estos perfectos obedientes no tenemos muchos [...] ¡Oh flaqueza grande!; ;Oh afrenta y de pocos entendida cuando el prelado dice al religioso!: ¿dónde queréis morar?; ¿qué oficio queréis hacer?; ¿en qué que-

248. Epistolario cristiano, 5, I, 102.

249. Desposorio espiritual, 6, II, 450.

250. Epistolario cristiano, 5, I, 101-102. 
réis que os consuele? Ténganse por ciegos y gente flaca los tales y humíllense y pidan con oraciones continuas que les abra los ojos Cristo [...] para que con san Pablo digan a sus prelados: padre, ¿que queréis que haga? Que mi voluntad, tirano cruel, ya la tengo desterrada de mí. [... A tal religioso] le será la religión paraíso de deleites y no galera penosa, como lo es y ha de ser a los que no saben negarse por Dios del todo"251.

El amor de Dios exige "que os contentéis con la vida común de todos los frailes. El que ayuna o vela sin voluntad del prelado su voluntad se hace y sin merecimiento trabaja [...]. Después que Dios se hizo hombre, parece cosa prodigiosa no humillarse los hombres, obedeciendo por Dios a sus mayores; y no basta obedecer algunas veces, sino siempre y hasta la muerte", como Cristo 252 . Siendo obedientes, "usamos de misericordia con nuestros prelados, de los que nos debemos compadecer, ayudándoles a llevar la carga pesada que en su oficio llevan [...]. Nuestro mayor es nuestro padre y nuestro pastor, a quien debemos quitar cuidados y enojos. Y si dar pena a nuestros hermanos es culpa, ¿cuánto mayor crimen será darla al que es nuestro padre? No hay contento que se compare a la alegría que damos a nuestros mayores, obedeciéndolos por Dios. En la obediencia que les tenemos se enseña el amor con que a Dios amamos, resplandece la humildad y negación de nosotros mismos y cuán mortificados tenemos nuestros apetitos y querer propio [...]. Despiértanos al uso de esta misericordia que hacemos con los prelados, obedeciéndolos, tener entendido que, cuanto en mayor dignidad están puestos, están en mayor peligro. El mayor oficio en la casa de Dios tiene mayor cuenta [...Se le pedirá $]$ cuenta particular de cada una de las almas que tuvieron debajo de su mano. Luego razón y justo es que hayamos misericordia y que nos compadezcamos de ellos, como de padres espirituales"253

\section{o) La vigilancia del superior}

Carga pesada la del superior. De ella tendrá que dar cuenta a Dios algún día. Él es el encargado de que el monasterio sea sepultura de los que allí viven; de que nadie se salga del camino; de que se cumplan estrictamente las observancias, y de que la disciplina tenga su asiento en los corazones. Él es el pastor que vela sobre el rebaño; el centinela siempre alerta, día y noche, para que nadie se desmande, y comience a actuar por su cuenta; la ronda que ase-

251. Ib., ib., 103.

252. $I b ., i b$.

253. Regla, 7, 27-29. 
gura la paz del convento. Vigilar, mirar, velar, guardar, llevar en los brazos, tener la espada de la palabra a punto, no dejar las armas de la oración, ser atalaya, centinela... Son algunas de las expresiones con que se describe su oficio.Todo ello en nombre de Dios. Para ayudarle en tan ardua tarea están los celadores, dos al menos; pero de este oficio no he encontrado ningún texto en el beato. Lo encontraremos en fray Luis.

"No teniendo oficio de prelada, solamente miréis vuestras faltas y quitéis los ojos de los descuidos ajenos"254. "El prelado ha de servir a los súbditos, proveyéndoles de lo temporal y halos de servir curándolos en sus enfermedades. Halos de sustentar en sus brazos, como la madre lleva al niño pequeño, sufriendo su flaqueza. Y aun halos de velar, como los que guardan de noche algún alcázar o ciudad. Finalmente halos de guiar, como Moisés encaminaba sus ovejas a lo interior del desierto, provocándoles a cosas espirituales y a seguir camino de perfección"255. "Declarar N. P. que al prelado pertenece este cuidado es significar lo que Dios dijo a Ezequiel: mira que te puse por atalaya y que si no dieres a entender al que peca su maldad, él perecerá y su alma te pediré yo a ti (Ez 3, 17-18). Esta amenza hace temblar el corazón de los que rigen y esta espada tan temerosa los admira y les atormenta para que comiendo no coman y durmiendo no reposen y duerman. ¡Oh, pluguiese a Dios que todos los que desean mandar y los que tan mal se les hace ser mandados, oyesen esta palabra que Dios a su profeta dijo y cada día dice a sus prelados!: El súbdito se condenará, no le corrigiendo y guardando tú; y a tu cuenta y para tu condenación será su perdición. Entendido tengo que la ambición de los hijos de Adán perecería y que las prelacías se llevarían como cruces pesadas, por fuerza y no por voluntad. Mire, pues, el prelado que es atalaya; considere que está puesto por centinela que no ha de dormir. Y pues el lobo Satanás y león rabioso, dice san Pedro que no duerme, siempre cercando las almas para destruirlas, ¿por qué dormirá y se descuidará el prelado en las guardar y defender?"256.

\section{p) Capítulo de culpis}

El capítulo de culpis, donde el religioso se acusaba de sus culpas, y podía ser acusado por otros, era una buena ocasión para humillarse y un buen momento para que el superior ejerciera su oficio, exhortara a la disciplina,

254. Epistolario cristiano, 6, I, 126.

255. Regla, 7, 15.

256. $I b ., 7,5$. 
diera avisos, corrigiera las faltas, e impusiera los castigos que creyera convenientes. Las acusaciones hay que recibirlas con humildad y no contestar a ellas, como no contestó Cristo, a no ser que se trate de calumnias gravemente escandalosas.

"En el capítulo es menester gran humildad, en el cual pensad que veis a Cristo, que viene a hacer juicio de todo el universo. Jamás excuséis vuestra culpa, cuando el callar no es escándalo a vuestras hermanas. Y como ordinariamente allí no se haga acusación de cosa grave, gran ejemplo será imitar a vuestro Esposo, Cristo, que aun siendo acusado falsamente no respondió [...]. En la paciencia principalmente consiste gran perfeccción [...]. Las culpas ajenas habéis de excusar y las vuestras acusarlas. A quien os acusa en el capítulo tened por mayor hermana [por superiora]. No le quitéis la habla ni mostréis triste rostro, que son muestras de poco espíritu y señal de gran flaqueza. Mirad que os llama vuestro Esposo paloma, porque no habéis de tener hiel ni querer venganza de nadie, aun en pocas cosas. Para todo es menester que Jesucristo sea puesto sobre nuestro corazón y su pasión esté escrita en nuestra memoria, delante de la cual nos parecerá ser nada lo que padecemos por su servicio"257.

\section{q) Castigos y disciplinas}

El castigo es necesario para restaurar el orden alterado por la culpa. Era esta una idea que venía rebotada desde la antigüedad clásica. Es el temor el que refrena a los hombres. En el momento en que se les deja solos, se desmandan, y son precisamente los de abajo los que más se rebullen.

San Isidoro recogió estas ideas y las transmitió a los siglos posteriores. El bautismo, dijo, redime del pecado original, pero "Dios el justo discriminó en la existencia a los hombres e hizo a unos esclavos y a otros señores, con el propósito de que la libertad de cometer el mal fuese restringida por los poderosos. Pues ¿cómo podría prohibirse el mal, si nadie temiese?”258. Orozco, sin embargo, apela en varias ocasiones a la nobleza del corazón del hombre, que se mueve más por la misericordia que por la justicia, pero sin cerrar la puerta a esta. Deber de todos los que tienen autoridad, repite, es "castigar" a los súbditos. A veces, esta palabra parece conservar el significado medieval de "corrección o amonestación"; pero otras no cabe duda sobre su significado de pena que se impone por una falta, sin duda porque era una forma más eficaz

257. Desposorio espiritual, 7, II, 453.

258. Sentencias, III, 47; cf. José VEGA, Ob. cit., 43-44. 
de corrección. "La tercera obra de misericordia es castigar o corregir a los que pecan. Puesto que son culpables todos los que tienen súbditos, mayormente los padres, no castigando sus hijos de las ofensas que hacen a Dios, de las cuales dice Salomón que el padre que no usa de castigo aborrece a su hijo"259.

Entre los castigos, los corporales. Son los más eficaces y ejemplares, que es otra de las funciones del castigo. Orozco no anda remiso en señalar a los padres la obligación que tienen de azotar a sus hijos, so pena de que si no lo hacen, Dios les castigue a ellos con la muerte incluso de estos 260 . El superior religioso castigaba también corporalmente, incluso con azotes o disciplinas. De que estos castigos originaban resentimientos y venganzas en quienes los recibían hay testimonio en el beato. Como del texto sobre el capítulo de culpis quien sepa leer concluirá que no todo el monte era orégano. Sobre las cárceles conventuales no he encontrado en él textos.

"Los prelados son obligados a hablar, corrigiendo a los súbditos y castigando a su tiempo a los que no cumplen la ley de Dios"261. "Hay que castigar a los mal sosegados para que se reposen y quieten, irles a la mano porque no albortoten a los otros"262. "Claro está que de no castigarse las faltas, no solo viene daño al que es descuidado, mas aun todo un convento recibe detrimento; porque otros toman osadía para cometer la misma culpa que el otro hizo, y aun los buenos reciben no pequeño escándalo en ver que lo mal hecho se disimula. Llama aquí emendar N. P. el amonestar con blandura al que pecó; porque muchas veces la misericordia hace mayor efecto que la justicia. La razón es porque al fin el corazón del hombre es noble y por nobleza se rinde y se vence algunas veces mejor. Y porque si esto no basta es menester castigo, dijo luego que corrija, quiere decir que reprenda y castigue. Como quien ya da cauterio de fuego a quien no bastó ungüento de misericordia"263. "Avisar aquí este santo doctor que con autoridad imponga a los súbditos la disciplina no es decir que sea riguroso, pesado y a todos importuno, sino que tengan entendido de él que, si menester fuere, que sabrá y osará castigar al que no hiciere lo que debe"264. Hay que honrar a los superiores y estos deben servir a los súbditos. "Mas el traidor que como Cam, hijo ingrato, se ríe y burla y pregona las afrentas y faltas de Noé, su padre y prelado, y el que no anda sino buscando achaques para inhabilitar al que, mereciéndolo él, le puso

259. Tratado del sacramento de la penitencia, 10, I, 335.

260. Cf. Epistolario cristiano, 7, I, 135, entre otros muchos textos..

261. Guarda de la lengua, 4, III, 419.

262. Regla, 7, 21.

263. $I b ., 7,4$.

264. Ib., 7, 25. 
la mano algún día y le castigó, mire no le venga el castigo de la maldición que le fue dada al hijo malo y tan ingrato a su padre"265.

"El que os preside mantenga, complacido, la disciplina; impóngala por el temor. $\mathrm{Y}$ aunque ambas cosas sean necesarias, prefiera más ser amado de vosotros que temido, pensando siempre que ha de dar cuenta de vosotros a Dios"266 Se trata de una máxima de gobierno muy citada por autores paganos, de los que pasó a los cristianos y a las reglas monásticas. Una máxima para ser escrita en los frontispìcios de las escuelas y monasterios (para ser escrita); pero ¿quién era capaz de aunar extremos tan opuestos, amor y temor? El superior o se daba a la misericordia y todo andaba manga por hombro, porque el religioso, no lo olvidemos, es menor de edad, un niño al que no se le puede dejar solo, que necesita siempre a su lado un ayo (lo dicen ellos, no yo); o se entregaba al rigor, y se convertía en el ogro del monasterio, que con el solo rumor de sus pasos imponía la disciplina ¿Dónde el superior que navegara con maestría en aguas tan encontradas? Solían decir, también lo dice Orozco, que es preferible inclinarse a la misericordia. Pero ¿quién que fuera responsable de su cargo, en el contexto social en que se ejercía, y con la doctrina que sobre él y sobre la vida religiosa se daba, podía inclinarse a la misericordia? Se ponía el ejemplo de Dios, Padre, bondad, misericordia; pero a renglón seguido este Padre azota con más rigor que cualquier otro, y hace cada escarmiento que tiembla el orbe. Un Padre que es a la vez Juez inexorable, y prepara su venganza para el día tremendo; al que deben imitar los padres de la tierra y todos los constituidos en autoridad para no dejar ni una sola falta sin castigo ejemplar. Un Padre que arroja al fuego inextinguible a los desobedientes; también, y sobre todo, a los superiores que no ejerzan su oficio de mantener la disciplina; de rondar el monasterio (cercar, dicen ellos), y espiar, y corregir, y zurrar la badana, si es preciso, a los que falten a la observancia. Al superior se le pedirá cuenta estrecha de todas las faltas de los súbditos.

Sea el superior ejemplo de observancia y disciplina, y gústele mantenerla en el monasterio. Los díscolos le odiarán, pero le amarán los sumisos. Uno solo de estos que le ame vale más que un escuadrón de aquellos que le aborrezca. "Gran aviso da aquí para saber regir y es que de necesidad el buen prelado ha de ser temido y amado: temido a los malos y amado de los buenos. [El maná era suave a los buenos y] revolvía el estómago a los malos. Bien así el prelado bueno por fuerza ha de ser agradable a los siervos de Dios y aborrecible a los imperfectos y descuidados [...]. Así lo han de ser los que en nues-

265. $I b ., 7,20$.

266. San AGUSTÍN, Regla, VII, 46. 
tros tiempos gobernaren como deben. $\mathrm{Y}$ en este caso más vale un bueno y más crédito da al prelado, siendo de él amado, que muchos flacos e imperfectos que le aborrezcan"267. "Lo que ha de querer y desear el prelado es ser más amado que temido. Ya cesó la ley del temor y vino la ley de amor. Por misericordia sustenta Dios al mundo y le rige no por rigor. Desee ser amado, porque el amor todo lo puede y todo lo hace suave. El amor todo lo sufre, como dice san Pablo (1Cor 13, 7). Todo es menester; mas eche mayor cantidad de aceite que de vino en las llagas de los descuidados que corrije (cf. Lc 10,34). Será amado más que temido, si fuere humilde de corazón, si honrare a sus súbditos, si sufriere emendando con paciencia, según lo aconseja san Pablo $(1$ Tes 5, 14); finalmente, si fuere muy temeroso de Dios y en todo muy disciplinado, providente y sabio. Y porque vale más dar cuenta de misericordia que no de exceso de justicia al buen pastor Jesucristo, concluye diciendo: considere siempre que ha de dar razón y cuenta a Dios de vuestras almas redimidas por su sangre y muerte preciosa"268.

\section{r) El juicio de Dios}

Con amor y temor cumpla el religioso lo que ha profesado: consagrarse a Dios, a él solo; vivir con Dios, él solo con Dios solo. Con amor a su Esposo, con temor de sus celos y de la estrecha cuenta que le ha de dar. Con amor y temor desempeñe el superior su oficio, sabiendo que dará de él cuenta muy rigurosa al justo Juez. Dará cuenta de sus actos y de los de sus súbditos. Las reglas monásticas insistían en ello; en ello insistían los espirituales y los predicadores, recordando a todos los que tenían autoridad aquel día de pavor. Allá, en la colada general, saldrán sus trapos sucios y los de sus subordinados, y de unos y otros tendrá que dar cuenta minuciosa..

"Razón es que el pastor que ha de dar tan estrecha cuenta de la oveja la conozca y dé remedio para su alma"269. Si el cristiano debe velar porque ha de dar cuenta de su vida, “¿cuánto más al prelado le importa velar siempre en oración, pues ha de dar dos cuentas espantosas? La una es de su conciencia y la otra de cada una de las ánimas de las cuales se hizo cargo"270. "El prelado, que es la guía y pastor que ha de dar cuenta de las almas de sus súbditos, corrija lo que ve que hay que enmendar"271."Las honras y dignidades traen

267. Ib., 7, 25 .

268. $I b ., 7,26$.

269. Tratado del sacramento de la penitencia, 7, I, 310.

270. Epistolario cristiano, 2, I, 21.

271. Regla, 7, 3 . 
consigo gran peligro y por tanto se han de llorar y gemir y no tomar contento en ellas; antes han de poner los ojos siempre en el juicio estrecho que los prelados han de dar de sus oficios, cuando se les pida cuenta particular de cada una de las almas que tuvieron debajo de su mano"272.

El principio se aplicaba a todos los que tenían autoridad. "En verdad te digo, se lee en el Quijote, que de todo aquello que la mujer del juez recibiere ha de dar cuenta el marido en la residencia [juicio] universal"273.

\section{s) Resumen}

¿Relaciones entre los religiosos?, podemos preguntarnos de nuevo. Los religiosos no conviven; obedecen. Conviven con Dios, únicamente con él. Desde esa convivencia y en virtud de ella, conviven en los lugares y tiempos señalados por la obediencia, y entonces hablan de Dios, solo de él. Por obediencia aceptan los oficios que les impone el superior, y se esmeran en cumplirlos por Dios y para Dios. Por amor de Dios y por obediencia salen de su encerramiento para ejercitarse en obras de misericordia o caridad, y por amor de Dios y por obediencia retornan a él lo más pronto posible, sin haber dejado mientras las hacían su soledad en Dios. El amor entre los religiosos es espiritual; aman lo común y público que hay en ellos, no lo particular y privado. Se aman en Dios, por Dios y para Dios, y en Dios, por Dios y para Dios aman a todos los hombres. Cualquier afecto humano queda excluido. Su solo aliento empañaría el espíritu. Quedan excluidos, sobre todo, aquellos afectos que son más peligrosos, como el amor filial o las relaciones con personas del otro sexo. Solo Dios basta. El solo debe llenar el alma. Soli Deo. Él solo, a solas, con Dios solo: así y únicamente así se perfecciona el religioso. Solus cum Solo.

Las relaciones humanas en la España del Siglo de Oro, también en el resto de Europa, eran pobres; con frecuencia, broncas y conflictivas. ¿Siglo de Oro los siglos XVI y XVII? Sí, si se atiende al arte, a la literatura, a la mística, al Imperio...; no, si se atiende a las relacions humanas, al hombre como persona. No hay un solo tratado sobre el tema; no podía haberlo, dada la mentalidad de los que podrían haberlo escrito.

José VEGA

(Continuará)

272. Ib., 7, 29.

273. Miguel de CERVANTES SAAVEDRA, El ingenioso hidalgo don Quijote de la Mancha, II parte, c. 42 (Clásicos Castellanos 19), Espasa-Calpe, Madrid 1968, vol. VII, p. 103. 